\title{
Van tweedekansonderwijs naar een leven lang leren : de veranderende betekenis van post-initiële scholing
}

Citation for published version (APA):

de Grip, A. (2000). Van tweedekansonderwijs naar een leven lang leren : de veranderende betekenis van post-initiële scholing. Maastricht University. https://doi.org/10.26481/spe.20000929ag

Document status and date:

Published: 29/09/2000

DOI:

10.26481/spe.20000929ag

Document Version:

Publisher's PDF, also known as Version of record

\section{Please check the document version of this publication:}

- A submitted manuscript is the version of the article upon submission and before peer-review. There can be important differences between the submitted version and the official published version of record.

People interested in the research are advised to contact the author for the final version of the publication, or visit the DOI to the publisher's website.

- The final author version and the galley proof are versions of the publication after peer review.

- The final published version features the final layout of the paper including the volume, issue and page numbers.

Link to publication

\footnotetext{
General rights rights.

- You may freely distribute the URL identifying the publication in the public portal. please follow below link for the End User Agreement:

www.umlib.nl/taverne-license

Take down policy

If you believe that this document breaches copyright please contact us at:

repository@maastrichtuniversity.nl

providing details and we will investigate your claim.
}

Copyright and moral rights for the publications made accessible in the public portal are retained by the authors and/or other copyright owners and it is a condition of accessing publications that users recognise and abide by the legal requirements associated with these

- Users may download and print one copy of any publication from the public portal for the purpose of private study or research.

- You may not further distribute the material or use it for any profit-making activity or commercial gain

If the publication is distributed under the terms of Article $25 \mathrm{fa}$ of the Dutch Copyright Act, indicated by the "Taverne" license above, 


\section{Van tweedekansonderwijs naar een leven lang leren}





\title{
Van tweedekansonderwijs naar een leven lang leren
}

De veranderende betekenis van post-initiële scholing

\author{
Rede
}

in verkorte vorm uitgesproken bij de aanvaarding van het ambt van bijzonder hoogleraar Bedrijfs- en Beroepsscholing en Arbeidsmarkt aan de Faculteit der Economische Wetenschappen en Bedrijfskunde van de Universiteit Maastricht op vrijdag 29 september 2000

door

Dr. A. de Grip 


\section{Voor mijn moeder}

Van tweedekansonderwijs naar een leven lang leren.

De veranderende betekenis van post-initiële scholing.

Dr. A. de Grip - Maastricht.

ISBN 90-5321-288-4 
Geachte Rector,

Dames en heren,

Zowel bij het bedrijfsleven, de overheid en het onderwijs is er de laatste jaren steeds meer aandacht voor de scholing van mensen die het dagonderwijs al hebben verlaten. We spreken hier wel van postinitiële scholing. Deze toenemende bellangstelling voor het post-initiële onderwijs heeft een tweetal oorzaken. In de eerste plaats stijgen in onze kennisintensieve samenleving in veel beroepen de opleidingseisen. Dit gaat vaak gepaard met een verschuiving in de gevraagde kennis en vaardigheden. In de tweede plaats is er een toenemende behoefte aan post-initiële scholing, omdat de kwalificaties waarover mensen beschikken tegenwoordig sneller verouderen vanwege bijvoorbeeld technologische vernieuwingen.

De betekenis van post-initiële scholing staat centraal in mijn leeropdracht. Deze leeropdracht richt zich op het onderzoeksterrein van de scholing van werkenden en werkzoekenden in relatie tot de ontwikkelingen op de arbeidsmarkt. Het is een onderzoeksterrein op het boeiende raakvlak tussen belangrijke maatschappelijke ontwikkelingen en ontwikkelingen in de economische theorievorming. Het overbruggen van de kloof tussen theorie en praktijk vind ik erg inspi- 
rerend. Bovendien zijn er op het terrein van mijn leerstoel interessante raakvlakken met andere wetenschappelijke disciplines. Ook hier wil ik graag bruggen slaan. De komende drie kwartier wil ik u hierover iets vertellen.

Ik wil achtereenvolgens ingaan op de volgende punten:

- Wat is de betekenis van post-initiële scholing in de kennisintensieve samenleving?

- Beschikken we over de juiste informatie over de investeringen in post-initieel onderwijs en de competentie-ontwikkeling van de beroepsbevolking?

- Wat weten we op basis van het empirisch economisch onderzoek op dit terrein?

- Welke inzichten biedt de economische theorievorming?

- Wat zijn de interessante raakvlakken met de vakgebieden van het Human Resource Management en de onderwijskunde?

- Wat betekent "een leven lang leren" voor de universiteit?

- Wat betekent het toenemende belang van het post-initieel onderwijs voor het overheidsbeleid?

\section{De ontwikkeling tot een kennisintensieve samenleving}

Upgrading en "key skills"

De toename van de opleidingseisen in veel beroepen wordt doorgaans aangeduid als de upgrading van de kwalificatie-eisen (zie bijvoorbeeld Borghans en De Grip, 2000 en De Grip en Van Loo, 2000). In 6 
de economische literatuur werden in eerste instantie twee oorzaken voor deze upgrading van de kwalificatie-eisen naar voren gebracht. We spreken hier wel van het "trade versus technology debate". Volgens auteurs als Wood (1994) is de upgrading van de opleidingseisen vooral het gevolg van een mondiaal specialisatieproces. De bedrijfssectoren waarin veel lager opgeleiden werkzaam zijn verplaatsen zich naar de minder ontwikkelde economieën. De westerse landen specialiseren zich in de meer kennisintensieve bedrijfssectoren. Anderen zien de technologische ontwikkeling als de belangrijkste oorzaak van de upgrading van kwalificatie-eisen (zie bijvoorbeeld Groot en De Grip, 1991, Machin en Van Reenen, 1998 en Wolff, 2000). Men spreekt in dit verband van skill-biased technological change. Technologische vernieuwingen leiden tot een toenemende complexiteit van functies en daarmee tot een toenemende vraag naar hoger opgeleiden. In feite gaat de idee van skill-biased technological change al terug naar Tinbergen's wedloop tussen de toenemende vraag naar geschoolde arbeidskrachten als gevolg van technologische ontwikkelingen en de stijging van de scholingsgraad van de beroepsbevolking (Tinbergen, 1975).

Technologische vernieuwingen bewerkstelligen bovendien vaak ook organisatorische veranderingen, zoals het schrappen van managementlagen, decentralisering, e.d., die op hun beurt de kwalificatieeisen in veel functies weer doen veranderen. In het verleden bestond vooral het beeld dat organisatorische veranderingen tot een versimpeling van het werk leidden (zie bijvoorbeeld Braverman, 1974). Meer recent onderzoek laat daarentegen zien dat organisatorische veranderingen de kwalificatie-eisen doen stijgen (zie bijvoorbeeld Caroli, 1998). Een belangrijke rol speelt daarbij dat massaproductie in alle sectoren plaats maakt voor op de consument afgestemd maat- 


\section{Van tweedekansonderwijs naar een leven lang leren}

werk. Hierbij wordt de kwaliteit van de geleverde goederen en de kwaliteit van de dienstverlening steeds belangrijker, zoals vorig jaar ook in de oratie van collega Lemmink (1999) naar voren werd gebracht. Zowel bij de meer op de proceskwaliteit gerichte kwaliteitszorg (ISO-certificering) als bij de meer op de algehele kwaliteit van de geleverde goederen of diensten gerichte kwaliteitszorg (Total Quality Management) is er veel aandacht voor het belang van goed opgeleid personeel (zie bijvoorbeeld Lynch en Black, 1998).

Technologische vernieuwingen, organisatorische veranderingen en de toenemende aandacht voor de kwaliteit van de dienstverlening zijn in feite sterk met elkaar verweven ontwikkelingen. Uit onderzoek van Bresnahan c.s. (1999) komt naar voren dat het gebruik van informatietechnologie gepaard gaat met diverse veranderingen in de organisatie en veranderingen in de aan de klant geleverde diensten. Skillbiased technological change is niet simpelweg het gevolg van het werken met gebruiksvriendelijke PC's. Dit PC-gebruik spitst zich immers grotendeels toe op tekstverwerking, spreadsheets en het maken van grafieken, wat slechts een zeer beperkte invloed heeft op de moeilijkheidsgraad van het werk. De toenemende vraag naar hoger opgeleiden is vooral het gevolg van het feit dat een optimaal gebruik van ICT veranderingen vereist in de organisatie ến bovendien legio mogelijkheden biedt de dienstverlening aan de klant te verbeteren. Deze complementariteit tussen de invoering van ICT, organisatorische veranderingen en de kwaliteit van de dienstverlening vormt de basis voor de skill-biased technological change.

Bresnahan c.s. (1999):

"Effective use of computer systems involves a great deal of invention by the using firms. This calls for new cognitive skills, having a deep 
understanding of one's own organization and one's customers' needs. This raises the demand for high levels of cognitive skills in managers and professionals. Even those managerial and professional workers who never touch computers are having their work transformed in this way, calling for more and more complex bodies of skill and knowledge".

In Nederland is de upgrading van de kwalificatie-eisen in veel functies ook een belangrijke oorzaak voor de sterk toenemende vraag naar hoger opgeleiden. In de arbeidsmarktprognoses die het ROA tweejaarlijks naar buiten brengt is deze upgrading de belangrijkste oorzaak van de toenemende krapte op de arbeidsmarkt voor hoger opgeleiden (zie bijvoorbeeld ROA, 1999). Dit komt duidelijk naar voren uit een doorrekening die Lex Borghans en Philip Marey van onze prognoses gemaakt hebben ten behoeve van het Centraal Economisch Plan 2000 van het Centraal Planbureau (2000). Wanneer er geen sprake zou zijn van een upgradingsproces zouden de verwachte knelpunten op de arbeidsmarkt voor hoger opgeleiden sterk afnemen, terwijl met name op VMBO-niveau het verwachte aanbodoverschot zou omslaan in een tekort.

De upgrading van de kwalificatie-eisen leidt echter niet alleen tot een sterk toenemende vraag naar hoger opgeleiden. Het leidt er ook toe dat voor de meeste uitvoerende beroepen tegenwoordig minimaal een MBO-opleiding wordt gevraagd. Ik heb dit eerder wel aangeduid als de "MBO-isering" van de vakarbeid (zie De Grip en Dekker, 1993). Op dit punt heerst er nog vaak een verkeerd beeld. Vakmensen associeert men dan ten onrechte nog met LTS'ers. In het onderwijsbeleid wordt een opleiding op MBO-niveau al geruime tijd gezien als de vereiste "startkwalificatie" voor de arbeidsmarkt. Voor zover men- 
sen dit niveau niet in het initièle dagonderwijs weten te behalen, is het van groot belang dat men dit niveau later wel bereikt. Bijvoorbeeld door het volgen van opleidingen waarin werken en leren worden gecombineerd, of door het volgen van op specifieke functies gerichte cursussen.

Daarnaast is er ook in toenemende mate oog voor het belang van een "leerrijke werkomgeving", die mensen in staat stelt bepaalde competenties te verwerven. In dit verband wordt ook gewezen op het belang van een certificering van "eerder verworven competenties" (EVC's) door middel van assesments, die de verborgen competenties van mensen zichtbaar maken. Deze EVC's zouden ook de competenties die mensen verwerven door "zelfstudie" in beeld kunnen brengen. Aangenomen mag worden dat in het kader van de kwaliteitszorg deze certificering van de competenties van de werkenden in bedrijven en instellingen de komende jaren sterk in belang zal toenemen.

Technologische en organisatorische ontwikkelingen en het toenemend belang van de kwaliteit van de dienstverlening leiden er niet alleen toe dat er hogere opleidingseisen worden gesteld. Ook is er naast de vakspecifieke kennis en vaardigheden een toenemende behoefte aan mensen die beschikken over communicatieve competenties, vaardigheden om problemen te signaleren en op te lossen en ICT skills (zie ook Howell en Wolff, 1991 en Green c.s., 2000). De Britse National Skills Task Force (1999) noemt een zestal "key-skills" waarover de werkenden in een kennisintensieve samenleving moeten beschikken:

- communicatieve vaardigheden;

- rekenen/wiskunde; 
- informatie- en communicatietechnologie kennis en vaardigheden;

- probleemoplossend vermogen;

- samenwerken met anderen ("teamwork");

- leervermogen ("leren te leren").

Interessant is de vraag of dergelijke key-skills het meest efficiènt in het initieel onderwijs of juist na het verlaten van de schoolbanken kunnen worden verworven. De uitkomsten van de door het ROA uitgevoerde $\mathrm{HBO}$ - en WO-Monitor wijzen er op dat de afgestudeerden vaardigheden als bijvoorbeeld het kunnen werken in teamverband erg belangrijk vinden voor een goede functievervulling. Maar ze geven ook aan dat deze vaardigheden het beste door "on-the-job training" kunnen worden verworven (ROA, 1999).

\section{Kwalificatieveroudering}

De tweede reden voor het toenemende belang van het post-initiële onderwijs is de noodzaak om het verouderd raken van de kwalificaties van werkenden te voorkomen. Sherwin Rosen (1975) was een van de eerste economen die hierop de aandacht vestigde. Het maatschappelijk belang van het voorkomen van kwalificatieveroudering wordt momenteel overigens nog vergroot door de toenemende "vergrijzing" van de beroepsbevolking. De maatschappelijke kosten van het vroegtijdig stoppen met werken via VUT-regelingen, WAO, e.d., worden door deze vergrijzing immers steeds groter.

In eerdere studies (De Grip en Van Loo, 1999, Van Loo c.s., 2000 en ROA, 2000) is door ons een typologie ontwikkeld, waarbij een vijftal 
verschillende oorzaken van kwalificatieveroudering wordt onderscheiden:

- slijtage als gevolg van het natuurlijk ouderwordingsproces, letsel of ziekte;

- atrofie vanwege het onvoldoende gebruiken van eerder verworven kwalificaties;

- functie-inhoudelijke kwalificatieveroudering vanwege technologische vernieuwingen en organisatorische veranderingen;

- kwalificatieveroudering vanwege een krimpende werkgelegenheid in een bepaald beroep of sector;

- bedrijfspecifieke kwalificatieveroudering vanwege reorganisaties of bedrijfssluitingen.

Slijtage en atrofie kunnen gezien worden als een "technische veroudering" van menselijk kapitaal (De Grip c.s., 1990). Slijtage leidt er in veel gevallen toe dat werkenden hun huidige functie niet langer adequaat kunnen uitoefenen. In dat geval is omscholing naar ander werk vereist om hun positie op de arbeidsmarkt te kunnen handhaven. Atrofie treedt vooral op wanneer mensen vanwege werkloosheid of zorgtaken hun vak langere tijd niet uitoefenen (Jones en Long, 1979 en Mincer en Ofek, 1980). De kennis en vaardigheden die men eerder heeft verworven nemen daardoor af. Vaak is dan enige herscholing vereist om weer een positie op de arbeidsmarkt te verwerven. Men spreekt in dit verband wel van "opfris-cursussen". Atrofie kan zich ook voordoen bij werkenden die lange tijd een functie vervullen waarin ze slechts een beperkt deel van hun kwalificaties gebruiken. Thijssen (1997) duidde dit aan als "ervaringsconcentratie". Hierdoor gaan eerder verworven kwalificaties verloren. 
De andere drie vormen van kwalificatieveroudering kunnen gezien worden als een economische veroudering van menselijk kapitaal. Daarbij gaat het niet zozeer om veranderingen in de capaciteiten van mensen, maar om een waardedaling als gevolg van veranderingen die zich in de buitenwereld voordoen. Zo kunnen de voor bepaalde functies vereiste kwalificaties veranderen door het gebruik van nieuwe technologieën en mede daaraan gerelateerde organisatorische veranderingen (zie bijvoorbeeld Pillay, 1998). Deze vorm van kwalificatieveroudering kan worden aangeduid als functie-inhoudelijke kwalificatieveroudering.

De economische veroudering van menselijk kapitaal kan ook het gevolg zijn van de ontwikkelingen op de arbeidsmarkt. Dit is het geval als de vraag op een bepaald segment van de arbeidsmarkt sterk krimpt. Immers, als bepaalde beroepen verdwijnen dan verliezen de voor deze functies vereiste kwalificaties hun waarde. Zo worden bijvoorbeeld door de inkrimping van de varkensstapel veel varkenshouders geconfronteerd met een dreigend verlies van werk waardoor hun vakkennis en vaardigheden hun marktwaarde verliezen (ROA, 2000).

De laatste vorm van kwalificatieveroudering die kan worden onderscheiden is de veroudering van bedrijfsspecifieke kwalificaties die optreedt wanneer mensen door bedrijfssluiting of reorganisaties van het bedrijf waarin ze werkzaam waren, hun baan verliezen. In dat geval gaat hun menselijk kapitaal dat bedrijfsspecifiek is verloren. Daarbij kan men denken aan kennis van specifieke apparatuur of procedures. 
In een binnenkort te verschijnen artikel van Jasper van Loo, Margot de Steur en mijzelf (Van Loo c.s., 2000) hebben we geprobeerd te onderzoeken of deze mogelijke oorzaken van kwalificatieveroudering zich op de Nederlandse arbeidsmarkt voordoen. Dit blijkt inderdaad het geval te zijn. Zo constateren we dat ICT en organisatorische veranderingen een versterkend effect hebben op de mate waarin werkenden in hun functie te kampen hebben met kwalificatieveroudering. Ook vinden we aanwijzingen voor het optreden van kwalificatieveroudering vanwege de verschuivingen in de werkgelegenheid en de noodzaak van werkkring te veranderen.

Wanneer mensen geconfronteerd worden met een veroudering van hun kwalificaties daalt de productiviteit van hun menselijk kapitaal. Men produceert dan minder, of dat wat men produceert verliest zijn waarde. Hierdoor kan men zich vaak moeilijk op de arbeidsmarkt handhaven. Om te voorkomen dat deze mensen werkloos worden of de arbeidsmarkt vroegtijdig verlaten, zijn er in principe twee mogelijkheden: hun beloning moet worden verlaagd, of hun productiviteit moet weer worden verhoogd (zie ook Gelderblom en De Koning, 1992). Om dit laatste te bewerkstelligen zijn er investeringen in bij- of omscholing vereist. Het risico van kwalificatieveroudering vormt dan ook de basis voor de maatschappelijk gevoelde noodzaak tot "een leven lang leren".

Een leven lang leren

Het toenemende belang van post-initiële scholing voor het verhogen en op peil houden van het menselijk kapitaal van de beroepsbevolking staat centraal in het overheidsbeleid dat zich richt op de ontwikkeling van de kennis-economie. In de door de Britse Labour regering 
bepleite "derde weg" vormt life-long learning zelfs het belangrijkste element om werkgevers- en werknemersbelangen te laten convergeren (Keep, 1999). In het witboek Teaching and learning; towards the learning society van de Europese commissie (1996) wordt ervoor gepleit dat bedrijven hun investeringen in fysiek kapitaal en de investeringen in opleidingen van hun personeel op gelijke voet behandelen. Ook de Nederlandse overheid is op dit punt niet achter gebleven. Zo publiceerde het kabinet in 1998 een nota waarin de beleidsagenda voor Een leven lang leren werd uiteengezet (Ministerie van Onderwijs, Cultuur en Wetenschappen, 1998). De gebruikte terminologie roept bij sommigen de associatie op van een veroordeling die over de gehele bevolking wordt uitgesproken. In andere tijden zou er vast gesproken worden van een levenslange leerplicht.

Hoewel dit alles wijst op de grote maatschappelijke waarde die aan het volgen van post-initiële opleidingen wordt toegekend, kan men zich afvragen in hoeverre hier nu werkelijk iets nieuws onder de zon is. Immers, ook in de jaren vijftig en zestig volgden veel mensen op latere leeftijd allerhande opleidingen. In de economisch administratieve sfeer bestond er feitelijk zelfs geen initiële beroepsopleiding op middelbaar niveau. De voor administratieve, secretariële en commerciële functies vereiste kwalificaties werden verworven door het volgen van het Praktijk Diploma Boekhouden, SPD opleidingen, de secretaresse opleidingen van Schoevers, e.d. Pas later werden deze beroepsopleidingen opgenomen in het initieel beroepsonderwijs op $\mathrm{MBO}$ - en $\mathrm{HBO}$-niveau.

Er is echter een belangrijk verschil tussen de participatie in het postinitieel onderwijs in de jaren vijftig en zestig en de huidige aandacht voor "een leven lang leren". Het vele doorleren in het verleden was 
grotendeels een vorm van wat men wel aanduidde als "tweedekansonderwijs" voor mensen die om financiële of sociaal-culturele redienen het initiële onderwijs veel eerder de rug toekeerden dan wat op basis van hun capaciteiten verwacht zou mogen worden. De reden voor het volgen van post-initieel onderwijs lag daarmee primair aan de aanbodzijde van de arbeidsmarkt. Financieringsproblemen waren een belangrijke oorzaak van de onderinvesteringen in de initiële opleiding van veel mensen. Het volgen van post-initiële opleidingen was in die tijd een substituut voor de participatie in het initiële onderwijs. Dit blijkt ook uit een onderzoek van Van Leeuwen en Dronkers (1992) op basis van het zogenaamde "Brabant-cohort". Zij constateren dat de in 1983 ruim veertigjarige mannen uit dit cohort, die afkomstig waren uit een eenvoudiger ouderlijk milieu vaker een post-initiële opleiding hadden gevolgd dan de mannen die uit een hoger milieu afkomstig waren.

De momenteel gevoelde maatschappelijke noodzaak de participatie in het post-initieel onderwijs te vergroten staat echter niet langer in het licht wan het tweedekansonderwijs. De noodzaak tot "een leven lang leren" komt nu voort uit de eerder genoemde ontwikkelingen aan de vraagzijde van de arbeidsmarkt. Er is daardoor veel minder sprake van een substitutie tussen de investeringen in initieel en post-initieel onderwijs, maar veeleer van een complementariteit tussen beide investeringen. Hierdoor verdwijnt de traditionele koppeling tussen het volgen van post-initiële scholing en het "omhoog komen" op de maatschappelijke ladder (Onstenk, 1997). Het accent verschuift naar het volgen van scholing om zich op de arbeidsmarkt te kunnen handhaven, dat wil zeggen mee te groeien met de eisen die er op de arbeidsmarkt worden gesteld. Voor zover men werkzaam is in functies waar sprake is van een sterke upgrading van de kwalificatie-eisen kan dit overigens betekenen dat een "opscholing" tot een hoger oplei- 
dingsniveau vereist is (zie ROA, 2000), maar in het algemeen kan men stellen dat, om de terminologie van Bartel (1992) te gebruiken, er een toenemend accent komt te liggen op "core training", die er op gericht is bij te blijven in het werk dat men uitoefent.

De verschuiving die er is opgetreden in de reden waarom mensen post-initiële opleidingen volgen komt ook duidelijk naar voren in de maatschappelijke betekenis van de Open Universiteit. Oorspronkelijk bedoeld als tweedekansonderwijs op het hoogste niveau, bleek de Open Universiteit in de praktijk vooral mensen die in het initieel onderwijs reeds een hoge opleiding hadden gevolgd op specifieke facetten bij te scholen. Zoals gezegd, is deze ontwikkeling geheel in het licht te plaatsen van de verschuiving in de maatschappelijke betekenis van post-initieel onderwijs. Eerst lag het maatschappelijk belang aan de aanbodzijde van de arbeidsmarkt. Nu ligt het maatschappelijk belang bij het aanbieden van leerwegen die van groot belang zijn voor de ontwikkelingen aan de vraagzijde van de arbeidsmarkt. Daarbij gaat het vooral om het verbreden van het initiële kwalificatieprofiel en de bij- of omscholing gericht op het voorkomen van kwalificatieveroudering.

Zoals ik hiervoor al aanstipte raakt dit aan de in de economische literatuur gestelde vraag in hoeverre er op individueel niveau sprake is van een complementariteit dan wel een substitutie tussen de investeringen in initieel onderwijs en de participatie in post-initiële opleidingen. Het empirisch onderzoek op dit terrein geeft aan dat er sprake is van een duidelijke complementariteit (zie bijvoorbeeld Shields, 1998 en OECD, 1999). Hoger opgeleiden participeren veel vaker in cursussen e.d. dan lager opgeleiden. Een verklaring hiervoor is dat de kosten om iets nieuws te leren voor hoger opgeleiden geringer zijn vanwege hun grotere leercapaciteiten. 
In een recent paper wijst Heckman (1999) op een nog verdergaande complementariteit tussen de participatie in het initiële en post-initiële onderwijs. Investeringen in human capital op jonge leeftijd bevorderen de investeringen in scholing op latere leeftijd vanwege wat hij aanduidt als de "fundamental dynamic features" van investeringen in menselijk kapitaal. Eerder verworven cognitieve skills vergemakkelijken het verder leren:

"Learning begets learning. Skills acquired early on make learning easier. More able people find leaming easier".

Wat nog belangrijker is: succes op school vergroot de motivatie om verder te Jeren:

"Early success breeds later success just as early failure breeds later failure".

Dit geeft aan dat uit de toegenomen maatschappelijke betekenis van life-long-learning niet de conclusie mag worden getrokken dat investeringen in het initieel onderwijs minder belangrijk worden. Integendeel, er is hier welhaast sprake van een paradox. Het leggen van een goed fundament voor wat betreft het leervermogen en de leermotivatie van mensen in het initieel onderwijs is cruciaal voor een samenleving die de maatschappelijke noodzaak van het vergroten van de participatie in het post-initiële onderwijs onderkent. Een leven lang leren betekent daardoor ook niet, zoals soms ten onrechte wordt gesuggereerd, dat het onderwijs dat we volgen moet worden uitgesmeerd over ons hele leven (zie ook Dronkers en Van Eck, 1998). Het verminderen van het aantal vroegtijdig schoolverlaters is dan ook een belangrijk middel om de "trainbaarheid" van de beroepsbevolking te vergroten. 


\section{Wat weten we van post-initiële scholing en competentie-ontwikkeling?}

Gezien het grote maatschappelijke belang van post-initiële scholing is het verbazingwekkend hoe weinig we weten van de omvang en de aard van deze investeringen in menselijk kapitaal. Meer in het algemeen is er erg weinig informatie over de wijze waarop mensen leren hun werk adequaat uit te oefenen en wat het effect is van deze leeractiviteiten. Al bladerend door de statistieken van het CBS valt op dat vrijwel alles wat in ons land wordt geproduceerd en verhandeld tot in de kleine details wordt bijgehouden. Hetzelfde geldt voor de investeringen in gebouwen, machines, e.d.; het zogenaamde fysieke kapitaal. Zo is bijvoorbeeld bekend dat er in Nederland in 1999152.793 geiten en 409.574 konijnen werden gefokt. Het aantal geiten in ons land is bovendien sterk stijgend met een toename in 1999 van maar liefst 20.676 geiten. Daarentegen liep het aantal konijnen in 1999 terug met maar liefst 33.899. Dit om een indruk te geven van de informatie waarover we in ons land beschikken.

Van de belangrijkste productiefactor in onze kenniseconomie weten we helaas veel minder. Wel wordt redelijk bijgehouden hoeveel mensen er in de verschillende bedrijfssectoren werkzaam zijn. Dankzij de Enquête Beroepsbevolking hebben we bovendien een indicatie van het opleidingsniveau van de beroepsbevolking en de participatie in postinitiële opleidingen in de vier weken voorafgaand aan de enquêtering'.

1. Ook in het OSA-Arbeidsaanbodpanel is op dit punt waardevolle informatie te vinden. 
De OECD (1999) waagt op dit punt ook een slag in de lucht te doen. $\mathrm{Na}$ het verlaten van het initieel onderwijs volgen we in Nederland in de rest van ons leven gemiddeld nog 1.512 uur scholing die voor het werk van belang is. Dit is net iets meer dan in de Verenigde Staten (1.403 uur), maar aanzienlijk minder dan in landen als Nieuw Zeeland (2.627 uur) en Canada (2.109 uur).

Van de omvang en de aard van de investeringen in het post-initieel onderwijs is echter in feite erg weinig bekend. Dit geldt zowel voor de kennis die de meeste bedrijven hebben van de scholingsinvesteringen van hun eigen personeel, als voor de beschikbare officiële statistieken. De beste databron is de Statistiek Bedrijfsopleidingen van het CBS, die om onbegrijpelijke redenen nog steeds niet met een vaste frequentie wordt uitgevoerd. De meest recente informatie waarover we momenteel kunnen beschikken heeft derhalve betrekking op 1993. In een samenleving die zich ontwikkelt als een kenniseconomie is het onbegrijpelijk waarom er wel jaarlijks informatie wordt verzameld over het aantal geiten en konijnen dat in ons land wordt gefokt, maar er geen jaarcijfers beschikbaar zijn over de participatie in post-initiële scholing ${ }^{2}$.

Ook zou er in de Enquête Beroepsbevolking meer aandacht moeten worden besteed aan het verzamelen van informatie over de participatie in scholingsactiviteiten. Daarbij moet er ook meer zorg worden besteed aan het adequaat verwerken van de informatie die er op dit

2. Bovendien zou de Statistiek Bedrijfsopleidingen, die momenteel alleen betrekking heeft op de particuliere sector, moeten worden uitgebreid met de zorgsector en de overheidlssector. 


\section{Van tweedekansonderwijs naar een leven lang leren}

punt reeds is. Zo is het opmerkelijk dat er in geen enkele statistiek van het CBS aandacht wordt besteed aan de mate waarin werkenden en niet-participerenden door het volgen van post-initiële scholing een hogere of andere opleidingsachtergrond weten te verwerven. In een analyse die ik heb verricht samen met Ank Jacobs hebben we laten zien dat deze informatie in principe uit de Enquête Beroepsbevolking kan worden gegenereerd (zie De Grip en Jacobs, 1999). Daarbij moesten we echter een aantal aannames maken, die bij een meer adequate verwerking van de antwoorden van de respondenten vermeden zouden kunnen worden. Uit onze analyse bleek overigens dat er in ons land jaarlijks maar liefst bijna 220.000 mensen door het volgen van een post-initiële opleiding een hogere of andere opleidingsachtergrond weten te verwerven. Het volgen van post-initiële scholing speelt vooral een belangrijke rol bij het verkrijgen van een kwalificatie op MBO-niveau. Circa 60\% van deze scholing vindt plaats op MBO-niveau. Ook zijn er jaarlijks maar liefst 50.000 mensen die door het volgen van een post-initiële opleiding een $\mathrm{HBO}$ of (post-)WO-niveau verwerven.

Uit onze analyses blijkt dat de bij- of omscholing via het post-initiële onderwijs zich concentreert bij de jongeren. Bij de leeftijdsgroep ouder dan 40 jaar bedraagt het percentage van de werkzame bevolking dat door het afronden van een post-initiële opleiding substantieel van kwalificatieprofiel verandert slechts $1,5 \%$. Bij de leeftijdscategorie van 30 jaar of jonger is dit ruim vier keer zo hoog. Bij deze leeftijdsgroep verwerft jaarlijks maar liefst ruim $6 \%$ van de werkzame bevolking via het post-initiële onderwijs een ander kwalificatieprofiel.

Het verzamelen van de juiste data over het post-initieel onderwijs gaat ook gebukt onder het feit dat nog onvoldoende is uitgekristalliseerd wat we precies willen meten. Hierbij gaat het enerzijds om de vraag 
welke kosten moeten worden meegeteld, maar anderzijds ook om de meer fundamentele vraag welke activiteiten tot de investeringen in menselijk kapitaal moeten worden gerekend. Een belangrijk probleem dat zich hier voordoet is dat naast het volgen van cursussen en opleidingen er ook ontzettend veel op de werkplek zelf kan worden geleerd. Als gevolg daarvan zijn er ook aanzienlijke verschillen tussen de trainingsparticipatie zoals die wordt gemeten in enquêtes onder werknemers en in enquêtes onder werkgevers. Uit onderzoek van Barron c.s. (1997) komt naar voren dat werkgevers maar liefst $25 \%$ meer trainingsactiviteiten rapporteren dan hun eigen werknemers. Onderzoek van Heckman en Smith (1995) geeft aan dat werknemers de tijd die zij op het werk aan training besteden onderschatten.

$\mathrm{Bij}$ het leren op de werkplek moet echter een onderscheid worden gemaakt tussen "on-the-job training" en "learning by doing". Bij "onthe job training" leert iemand onder begeleiding van een meer ervaren medewerker de finesses van het vak. In dat geval zijn er begeleidingskosten en zal het werk op bepaalde momenten stil liggen, omdat er dingen moeten worden uitgelegd. Bij "learning-by-doing" (Arrow, 1962 en Killingsworth, 1982) is er daarentegen meer sprake van een automatisch leerproces. Dit "learning-by-doing" gaat ogenschijnlijk niet met kosten gepaard, in de zin dat er geen formele begeleider is. Echter, "learning-by-doing" betekent doorgaans dat iemands productiviteit in het begin nog niet op het gewenste niveau ligt. Voor zover deze lagere productiviteit niet in het loon van de betrokkene tot uiting komt, brengt dit voor de werkgever kosten met zich mee. Het begrip "learning-by-doing" raakt echter ook aan het eerder genoemde begrip "leerrijke werkomgeving". In een uitdagende werkomgeving zal iemand waarschijnlijk veel kunnen leren zonder dat dit gepaard gaat met een lagere productiviteit. Met name bij "learning by doing" is het 
moeilijk de participatie te meten. Men zou er echter gericht naar kunnen vragen (zie ook Lynch, 1998).

Recentelijk is vanuit het ROA een onderzoek gedaan waarin nauwgezet gekeken is op welke wijze werknemers binnen een bepaald bedrijf bepaalde competenties hebben verworven (Borghans c.s., 2000). Het onderzoek had betrekking op zogenaamde "servicemedewerkers" bij het ABP/USZO. Dit zijn mensen die aanvragen voor uitkeringen behandelen en de gegevens van klanten beheren. Om u een beeld te kunnen geven welk soort informatie dergelijk onderzoek kan opleveren, zal ik er iets meer over zeggen. In een paper van Lex Borghans en Jasper van Loo (2000) naar aanleiding van dit onderzoek wordt een vijftal bronnen van kwalificaties onderscheiden:

- de initiële opleiding;

- bedrijfscursussen;

- werkervaring;

- zelfstudie;

- talent.

Uit het onderzoek komt naar voren dat ervaring en zelfstudie een veel belangrijkere rol spelen bij het verwerven van verschillende competenties, dan de formele cursussen en de initiële opleiding die men heeft gevolgd. De initiële opleiding is alleen de belangrijkste kwalificatieroute voor schrijf- en rekenvaardigheden. Hierbij moet natuurlijk wel worden bedacht dat de initiële opleiding van mensen ook de basis kan vormen voor de latere kennisverwerving op andere terreinen. Formele cursussen zijn alleen belangrijk voor het verwerven van computervaardigheden, hoewel ook hier werkervaring en zelfstudie een belangrijke rol spelen. De voor het werk vereiste specialistische kennis en het kunnen adviseren van klanten wordt daarentegen vooral 
door werkervaring verkregen. Terwijl de vaardigheid om het werk te kunnen plannen vooral een kwestie is van zelfstudie.

Een belangrijke lacune in de beschikbare informatie is ook het ontbreken van een statistische bron die gericht is op het in kaart brengen van de competenties waarover werkenden op de verschillende segmenten van de arbeidsmarkt beschikken. Er is tot op heden ook nog veel te weinig aandacht geweest voor de wijze waarop de competenties waarover mensen beschikken, moeten worden gemeten. Deze metingsproblematiek stond ook centraal in de begin dit jaar door Lex Borghans en Francis Green in Canterbury georganiseerde conferentie over Skill Measurement and Economic Analysis.

Het adequaat in beeld brengen van de verschillende competentieaspecten van human capital is van groot belang om goed inzicht te kunnen krijgen in het belang van bepaalde competenties voor de productiviteit van werkenden in uiteenlopende functies. In het zojuist genoemde onderzoek onder de servicemedewerkers van ABP/USZO is geprobeerd de competenties waarover mensen beschikken in kaart te brengen. Daarbij is aangesloten op de vraagstelling van het in het Verenigd Koninkrijk opgezette Skills Survey of the Employed British Workforce (zie bijvoorbeeld Green c.s., 2000). In deze Skills Survey worden niet alleen de competenties waarover mensen beschikken nauwgezet in kaart gebracht, maar ook de competenties die vereist zijn voor de functie die men uitoefent, de vereiste inwerktijd, de deelname aan trainingen, het salaris, het risico van verlies van werk, e.d. Bovendien kan deze informatie worden verbijzonderd naar bedrijfssector, beroep en opleiding.

Ook de vanuit de OECD geïnitieerde International Adult Literacy Survey is op dit punt een belangrijk initiatief. Het OECD onderzoek meet de "functional literacy" van volwassenen. Hierbij gaat het om de 24 
vaardigheid om schriftelijke informatie te begrijpen en adequaat te gebruiken. Daarbij wordt zowel gekeken naar het begrijpend lezen van teksten, het begrijpen van formulieren, tabellen en grafieken als naar de rekenvaardigheid waarover iemand beschikt. Op alle drie punten worden verschillende niveaus van "functionele geletterdheid" onderscheiden (OECD, 1995).

De uitkomsten van dit OECD onderzoek laten zien dat er grote verschillen bestaan in de competenties van mensen die formeel hetzelfde opleidingsniveau hebben. Nog groter zijn de verschillen in de competenties tussen de mensen met eenzelfde opleidingsniveau in de verschillende landen. Dit laatste betekent dat deze International Adult Literacy Survey een geheel ander beeld geeft van de relatieve kennisintensiteit van de beroepsbevolking in verschillende landen, dan de statistieken van het formele opleidingsniveau van de beroepsbevolking (Cornet, 2000). Zo komt Nederland op basis van de cijfers van het opleidingsniveau van de beroepsbevolking naar voren als een land met relatief veel lager opgeleiden en relatief weinig hoger opgeleiden, terwijl het International Adult Literacy Survey een veel positiever beeld geeft van de kennisintensiteit van de Nederlandse beroepsbevolking. Voor de Verenigde Staten geldt precies het omgekeerde. Voor de V.S. blijken de cijfers over het formele opleidingsniveau van de beroepsbevolking de kennisintensiteit van de beroepsbevolking te overschatten.

Het is van groot belang meer inzicht te krijgen in de competenties waarover de beroepsbevolking in ons land beschikt. Ik wil hier pleiten voor het opzetten van een grootschalige enquête naar de competentieontwikkeling van de beroepsbevolking in Nederland en de mate waarin de kwalificaties van werkenden op bepaalde punten tekortschieten: de zogenaamde "skills shortages" (zie Borghans c.s, 1998). 
Het ontbreken van een dergelijke monitoring van de vereiste competenties en de competenties waarover werkenden en werkzoekenden beschikken is een pijnlijke omissie in de statistische informatie die er momenteel over de productiefactoren in onze kenniseconomie beschikbaar is.

In deze "Competentie Monitor" zou er naast de vakspecifieke kwalificaties ook oog moeten zijn voor de eerder genoemde "key skills". Het Britse Skills Survey kan daarbij als voorbeeld dienen. Op deze manier kunnen de verschuivingen die zich voordoen in de voor een adequate uitoefening van het werk vereiste valktechnische competenties en key skills systematisch in beeld worden gebracht.

Het is het mijns inziens ook van groot maatschappelijk belang de informatie over de context waarin investeringen in post-initiële opleidingen plaatsvinden substantieel te verbeteren. Een voorbeeld hiervan is de informatie over de aansluiting tussen de gevolgde initiële opleiding en de functie waarin men werkzaam is, zoals in de op initiatief van het ROA opgezette schoolverlaters-enquêtes wordt gemeten. Dit maakt het mogelijk een relatie te leggen tussen de participatie in postinitiële scholing en de aansluiting tussen de eisen die de functie stelt en de in de initiële opleiding verworven competenties.

Ook is het belangrijk om meer inzicht te krijgen in de betekenis die het scholen van werkenden heeft in het bedrijfsbeleid van grote en kleine bedrijven. Een enquête onder werkgevers zou hier meer zicht op moeten geven. Weliswaar worden er in het tweejaarlijkse werkgeverspanel van de OSA op dit punt enkele vragen gesteld. Het gaat hier echter niet alleen om het periodiek in kaart brengen van de faciliteiten die bedrijven bieden, maar ook om de factoren die een rol 
spelen in de besluitvorming. Daarbij kan men bijvoorbeeld denken aan het al dan niet bestaan van opleidingsbudgetten, de motieven voor het scholen van medewerkers, de factoren die het trainen van personeel bemoeilijken, de afweging tussen intern en extern opleiden, de afweging tussen on-the-job training en formele scholing, het kunnen volgen van scholing in werktijd of in eigen tijd, de wijze waarop men kosten en baten van scholing tevoren indiceert en ex post de baten meet, de relatie tussen scholing en beloning, e.d.

Ik wil hier pleiten voor het opzetten van een gecombineerd bedrijvenwerknemers panel, waarin zowel informatie over het trainingsbeleid van bedrijven, als informatie over de trainingsparticipatie van de verschillende groepen werkenden wordt verzameld. Dit maakt het mogelijk om beter inzicht te krijgen in de mate waarin bedrijfskenmerken en werknemerskenmerken van invloed zijn op de trainingsparticipatie (zie ook Lynch, 1998).

Naast het verzamelen van de vereiste informatie is het ook van groot belang hieruit de beleidsrelevante informatie te genereren. Het door mijzelf met anderen opgezette Werkgelegenheid en Scholing Observatorium is een goed voorbeeld van de wijze waarop, op basis van de beschikbare databronnen, periodiek informatie kan worden gegenereerd, die is toegespitst op een specifieke informatiebehoefte van de overheid en het bedrijfsleven, in dit geval het scholingsbeleid gericht op het behoud van werk. Het observatorium richt zich op het in beeld brengen van de verschillende mogelijke oorzaken van kwalificatieveroudering (zie ROA, 2000)3. Dit maakt het mogelijk een relatie te

3. Ook in het eerder genoemde ROA-onderzoek onder de dossiermedewerker wan het ABP/USZO was dit een belangrijk aandachtspunt. 
leggen tussen de noodzaak om door aanvullende training de kwalificaties van bepaalde groepen werkenden op peil te houden en de feitelijk door deze groepen geleverde scholingsinspanningen. Een dergelijke monitoring kan een belangrijke signaalfunctie hebben voor zowel bedrijven als individuele arbeidskrachten, omdat het een beeld geeft van de risico's op verlies van werk vanwege kwalificatieveroudering. De beschikbaarheid van adequate informatie op dit punt is vanzelfsprekend ook een noodzakelijke voorwaarde voor een effectief overheidsbeleid. Daarbij kan in het bijzonder in het oog gehouden worden op welke punten er vanuit maatschappelijk oogpunt sprake is van "marktfalen" vanwege het ontbreken van de juiste prikkels bij werkgevers of de werkenden zelf. Op deze wijze ontstaat een richtinggevend kader voor het beleid ter voorkoming van werkloosheid of vroegtijdige uittrede uit de arbeidsmarkt als gevolg van kwalificatieveroudering.

Het voorgaande samenvattend kan echter slechts worden geconcludeerd dat we veel te weinig weten over de omvang en de aard van de investeringen in menselijk kapitaal na het verlaten van het initieel onderwijs en de competenties waarover mensen in hun werk moeten beschikken. Het ontbreken van deze informatie bemoeilijkt het onderzoek naar de betekenis van de investeringen in human capital voor de productiviteit van mensen in verschillende functies en de micro- en macro-economische implicaties van bepaalde "skills shortages". We missen daardoor ook het inzicht in de mate waarin werkenden te kampen hebben met kwalificatie-veroudering en de wijze waarop hier het meest efficiënt zou kunnen worden geanticipeerd. We beschikken derhalve niet over de informatie waarover een kenniseconomie zou moeten beschikken. Dit is een slechte zaak. Als menselijk kapitaal voor de ontwikkeling van onze samenleving van even groot belang is 
als fysiek en financieel kapitaal dan verdient het ook hetzelfde instrumentarium.

\section{Economisch empirisch onderzoek}

$\mathrm{Na}$ deze verkenning van de lacunes in de beschikbare databronnen met betrekking tot de investeringen in post-initiële scholing en de competentie-ontwikkeling van de beroepsbevolking, zou ik nu willen ingaan op hetgeen we weten op basis van het empirisch economisch onderzoek op dit terrein.

Het economisch onderzoek met betrekking tot het post-initieel onderwijs richt zich vooral op het rendement van investeringen in post-initiële scholing en het verklaren van de deelname aan het postinitiële onderwijs. Daarnaast is er veel aandacht voor studies naar de effectiviteit van scholingsprogramma's voor werkzoekenden. Op de eerstgenoemde rendementsstudies, waaraan veel haken en ogen zitten, zal ik hier niet ingaan (zie bijvoorbeeld OECD, 1999 en Goux en Maurin, 2000). Wel wil ik opmerken dat vrijwel alle studies op dit terrein geen onderscheid weten te maken tussen verschillende soorten training, het niveau van de gevolgde training, e.d. (zie Blundell c.s., 1999). Het zou waardevol zijn juist op dit punt verder onderzoek te doen.

Verklaringen voor de participatie in post-initiële opleidingen

Diverse studies richten zich ook op de vraag wie er vooral scholing volgen. Figuur 1 geeft een overzicht van de belangrijkste resultaten 
van de literatuur die gericht is op het traceren van de belangrijkste determinanten voor de participatie in post-initiële training.

Over de hogere scholingsparticipatie van hoger opgeleiden heb ik het hiervoor al gehad. Op een aantal andere in de figuur aangegeven factoren die van invloed zijn op de scholingsparticipatie van werkenden zal ik nu ingaan.

De kosten-baten analyse die centraal staat in de human-capital theorie biedt een goed theoretisch kader voor het verklaren van de geringere scholingsdeelname van bepaalde groepen mensen. Zo kan de lagere scholingsparticipatie van ouderen verklaard worden vanuit de geringere tijd dat hun investeringen in scholing kunnen renderen. Op dit punt is er vanzelfsprekend ook een duidelijke samenhang met de mogelijkheden die men heeft tot vervroegde pensionering e.d.

Vanuit beleidsoogpunt is deze wisselwerking van groot belang. Enerzijds vermindert de scholingsparticipatie van ouderen de arbeidsmarktuitstroom van oudere arbeidskrachten doordat deze scholingsinvesteringen hun productiviteit op peil houden. Anderzijds verminderen VUT-regelingen e.d. het rendement van dergelijke scholingsinvesteringen.

Volgens de cijfers van het OSA participeerde in de periode 1997. 1998 slechts $24 \%$ van de werkenden van 55 jaar en ouder in een scholingsactiviteit, tegenover $41 \%$ van de werkenden in de leeftijdsgroep van 35-44 jaar. Het verschil tussen beide leeftijdsgroepen is volgens de OSA-cijfers overigens in korte tijd sterk teruggelopen. 


\section{Van tweedekansonderwijs naar een leven lang leren}

\section{Figuur 1}

Verklaringen voor de participatie in post-initiële opleidingen.

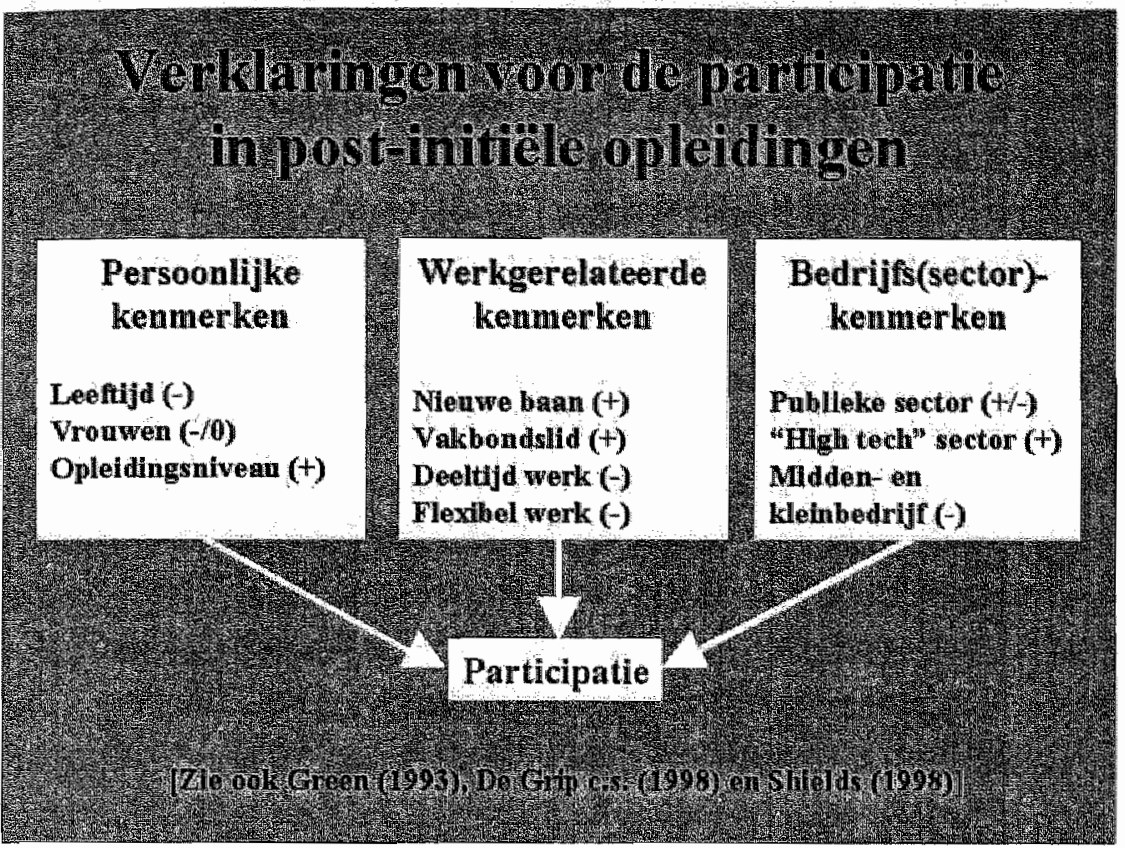

In de jaren 1993-1994 nam slechts 5\% van de werkenden van 55 jaar en ouder aan een cursus deel, tegenover $26 \%$ van de $35-44$ jarigen (zie Fouarge c.s., 1999)4.

De relatief lage scholingsparticipatie van de oudere werknemers geeft aan dat het verhogen van de arbeidsparticipatie van ouderen een nog verdere toename van de scholingsinvesteringen van de oudere arbeidskrachten vereist.

4. In de cijfers van de Enquête Beroepsbevolking van het CBS is deze toename van de scholingsparticipatie overigens niet terug te vinden. 
De human-capital theorie geeft ook een verklaring voor de geringe scholingsparticipatie van deeltijders, zoals ook naar voren komt uit cijfers van de OSA (zie ROA, 2000). Wanneer iemand in deeltijd werkt is de werktijd warin men de vruchten plukt van de hogere productiviteit immers geringer. Bij flexibele arbeidskrachten is het daarentegen vooral de onzekerheid over het voortduren van de arbeidsrelatie die de bereidheid om te investeren in scholing vermindert (Crawford, 1990). Het is in dat geval immers onzeker of een werkgever zich het hogere rendement wel kan toe-eigenen, terwijl ook werknemers met een flexibel contract niet weten of ze zullen profiteren van een werkgerelateerde scholingsinvestering. Uit onderzoek dat ik samen met Nicole Jonker verrichtte kwam naar voren dat de werkenden met een vast contract ongeveer twee keer zo vaak scholing volgen dan degenen met een flexibel contract. Bijna $40 \%$ van dit verschil kan verklaard worden uit de geringere bereidheid van werkgevers om te investeren in de scholing van flexwerkers (Jonker en De Grip, 1999).

Voor zover vrouwen zich langere tijd van de arbeidsmarkt terugtrekken vanwege de zorgtaken voor hun kinderen, zal de bereidheid om in aanvullende training te investeren ook geringer zijn. Dit ongeacht of de werkgever of de betrokkene zelf de trainingskosten voor haar rekening neemt (De Grip c.s., 1990). Echter, wanneer de werkgever de scholingsinvestering moet financieren zal deze de baten van de schollingsinvestering baseren op de verwachte investeringshorizon, gebaseerd op het gemiddelde arbeidsmarktparticipatiegedrag van vrouwen (Green, 1993). Gezien de sterk toenemende arbeidsmarktparticipatie van vrouwen mag verwacht worden dat de verschillen in trainingsparticipatie tussen mannen en vrouwen zullen afnemen. Dit 
blijkt ook uit onderzoek van bijvoorbeeld Greenhalgh en Mavrotas (1996).

Degenen die werkzaam zijn in het midden- en kleinbedrijf wolgen ook veel minder scholing. De scholingsparticipatie van de werkenden in de bedrijven met minder dan tien werknemers bedraagt slechts de helft van de cursusdeelname van de werkenden in de bedrijven met meer dan 100 werknemers (zie ROA, 2000). Aangenomen mag worden dat er bij het midden- en kleinbedrijf sprake is van een onderinvestering in het vereiste menselijk kapitaal. Vaak zijn er bij de kleinere bedrijven praktische problemen bij de vervanging van werknemers die een cursus volgen. Waarschijnlijk is het probleem echter meer fundamenteel. Vanuit de human-capital theorie kan het "marktfalen" op dit punt worden verklaard uit het risico dat werkgevers lopen dat een door hen opgeleide werknemer door een concurrent wordt weggekocht. Dit wordt doorgaans aangeduid als het "poaching" risico. Dit risico zal zich vooral voordoen op marktsegmenten waarop meerdere kleinere bedrijven hun personeel werven. In feite is hier sprake van een "prisoners-dilemma" (De Grip, 1987a). Door het risico dat concurrenten de opgeleide werknemers wegkopen wordt er minder geïnvesteerd in de scholing van de werkenden dan vanuit bedrijfsoogpunt en maatschappelijk oogpunt optimaal is.

Degenen die slechts kort in een bepaalde functie werkzaam zijn volgen vaker aanvullende scholing. Waarschijnlijk is er voor veel functies een leertraject vereist waarin men zich de voor een adequate uitoefening van de functie vereiste bedrijfsspecifieke kennis en waardigheden eigen maakt. Ook kan de noodzaak bestaan om de kloof tussen de door de werknemer gevolgde initiële opleiding en de kwalificatie-eisen voor de functie die men uitoefent te overbruggen. 
Dit zal vooral het geval zijn wanneer werkgevers bij een tekort schietend aanbod van mensen met een opleidingsachtergrond waarnaar hun voorkeur uitgaat, genoodzaakt zijn mensen aan te trekken met een minder goed bij de functie aansluitende opleidingsachtergrond. De assignmenttheorie biedt een theoretisch raamwerk voor de analyse van de betekenis van aanvullende scholing voor het overbriggen van deze kloof (zie Van Eijs en Heijke, 2000).

Uit empirisch onderzoek van Greenhalgh en Mavrotas (1996) komt naar voren dat het personeel in bedrijfssectoren die veel Research \& Development verrichten, relatief vaak opleidingen volgt. De onderzoeksresultaten van Lynch en Black (1998) bevestigen dit en laten ook zien dat naast technologische vernieuwingen ook organisatorische veranderingen een belangrijke impuls vormen voor een hoge trainingsparticipatie. Uit hun analyses komt naar voren dat bedrijven waar sprake is van Total Quality Management, benchmarking en/of zelfsturende teams een hogere trainingsparticipatie kennen. Dit wordt bevestigd door analyses in de Employment Outlook 1999 van de OECD (1999). Hieruit komt naar voren dat in organisaties waar sprake is van functieroulatie, quality circles, Total Quality Management, zelfsturende teams, e.d., een groter deel van het personeel participeert in trainingsactiviteiten.

Het eerder genoemde onderzoek onder de servicemedewerkers van ABP/USZO (Borghans c.s., 2000) gaat op dit punt meer in de diepte. Uit het onderzoek komt naar voren dat veranderende regelgeving, ICT ontwikkelingen en organisatorische veranderingen tot ingrijpende veranderingen van het werk leiden. Met name wanneer er sprake is van veranderingen in het werk vanwege automatisering, of veranderingen in de regelgeving met betrekking tot de uitkeringen, worden 
er door de medewerkers cursussen gevolgd. Bij organisatorische veranderingen krijgen de medewerkers daarentegen vrijwel geen ondersteuning door het volgen van cursussen, maar is er vaker sprake van begeleiding op de werkplek door collega's. Dit wijst er op dat het kennelijk moeilijk centraal vanuit de organisatie is vast te stellen op welke wijze de competentie-ontwikkeling van de medewerkers het beste ondersteund kan worden. Juist deze organisatorische veranderingen brengen voor veel medewerkers overigens de meeste problemen met zich mee. Dit pleit er voor dat werknemers een grotere verantwoordelijkheid krijgen om zelf initiatieven voor hun competentieontwikkeling te nemen.

Werven of trainen?

Een interessant aandachtspunt in het empirisch onderzoek met betrekking tot de post-initiële scholing van werkenden is ook de relatie tussen het wervingsbeleid en het scholingsbeleid van werkgevers. Bedrijven hoeven niet per se hun eigen personeel te trainen om meer menselijk kapitaal in huis te krijgen. Zij kunnen de benodigde bekwaamheden ook aantrekken op de arbeidsmarkt. In een artikel dat ik samen met Loek Groot schreef bestempelden we dit als de "recruitment" versus "trainingsoptie" (Groot en De Grip, 1991).

Om de in de verschillende bedrijfssectoren gehanteerde human-capital strategie te kunnen typeren heb ik in de onderstaande figur de scholingsinvesteringen ${ }^{s}$ van de verschillende bedrijfssectoren afgezet tegen het gemiddeld opleidingsniveau van de werkenden. Op deze

5. Hierbij is gebruik gemaakt van cijfers uit 1993. Meer recente cijfers zijn zoals gezegd momenteel niet beschikbaar. 
wijze kunnen vier human-capital strategieën worden onderscheiden (zie ook Van Smoorenburg en De Grip, 1997).

Er zijn bedrijfssectoren die personeel met een hoog opleidingsniveau werven en daarnaast zelf ook nog eens fors investeren in de verdere scholing van hun personeel. Deze sectoren accumuleren veel menselijk kapitaal. We kunnen dit bestempelen als de "accumulatie strategie". Voorbeelden hiervan zijn de financiële instellingen en de energie- en waterleidingbedrijven. Daartegenover staan de sectoren waarin veel laag opgeleiden werken en die hun personeel ook nauwelijks trainen. We kunnen hier spreken van een "weinig vaardigheden strategie". Een voorbeeld hiervan is de textiel-en kledingindustrie.

Er zijn echter ook bedrijfssectoren waarin de werknemers weliswaar een gemiddeld laag opleidingsniveau hebben, maar waar wel fors wordt geïnvesteerd in aanvullende scholing. Deze sectoren volgen een "maak strategie". Ze creëren zelf het in de sector benodigde menselijk kapitaal. Een goed voorbeeld hiervan is de sector vervoer en communicatie. Ten slotte zijn er nog de bedrijfssectoren waarin een hoog gemiddeld opleidingsniveau gecombineerd wordt met geringe investeringen in aanvullende scholing. Deze sectoren volgen een "koop strategie". Ze kopen het benodigde menselijk kapitaal op de externe arbeidsmarkt. Met name de zakelijke dienstverlening volgt deze strategie. 


\section{Van tweedekansonderwijs naar een leven lang leren}

Figuur 2

Werven of trainen?

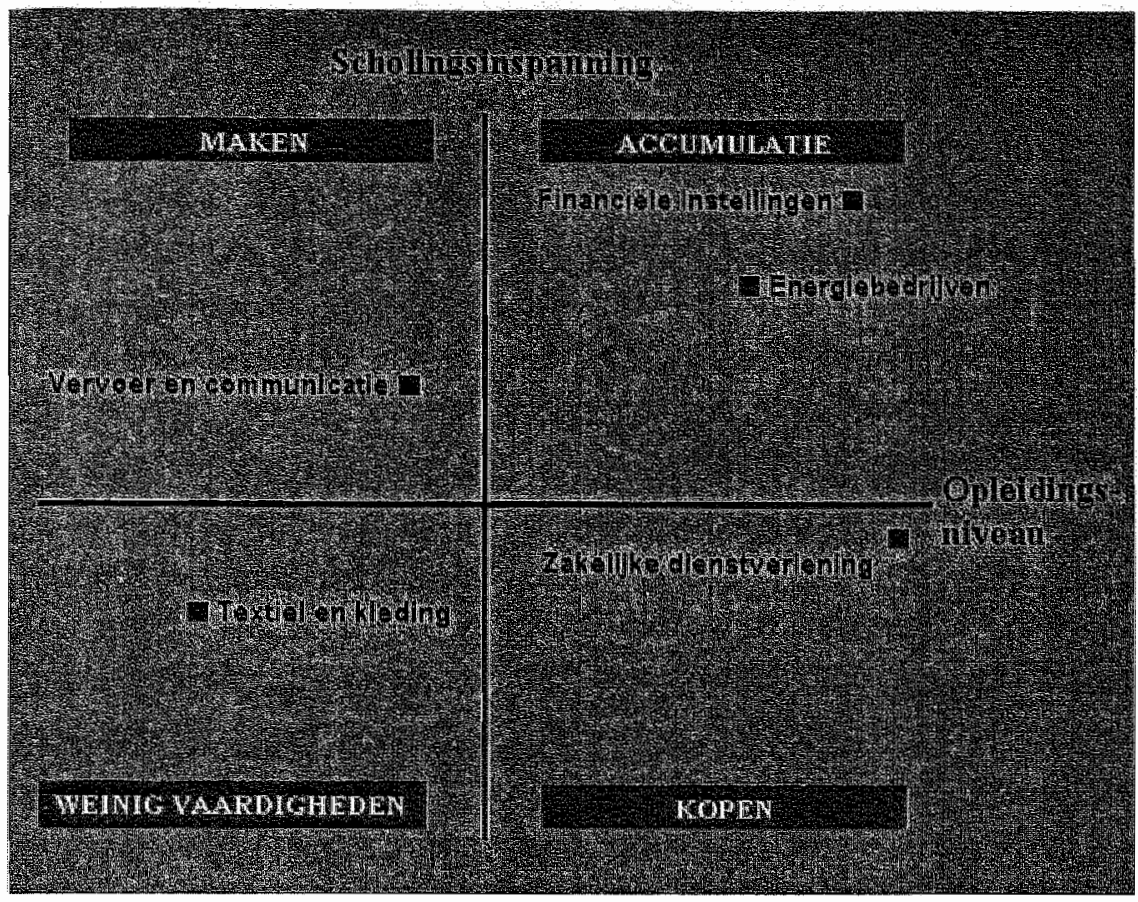

Er is weinig onderzoek naar de relatie tussen de situatie op de arbeidsmarkt en de scholingsparticipatie van werkenden. In een aantal studies is onderzocht in hoeverre de scholingsparticipatie van werkenden beïnvloed wordt door de hoogte van de werkloosheid (zie bijvoorbeeld Arulampalam c.s., 1996). Verwacht zou kunnen worden dat bij een hoge werkloosheid werkgevers minder geneigd zullen zijn om in aanvullende scholing te investeren. Dit is echter alleen het geval als het werkloze arbeidsaanbod over de vereiste kwalificaties beschikt. De genoemde onderzoeken vinden overigens geen significante relatie tussen de hoogte van de werkloosheid en de scholings- 


\section{Van tweedekansonderwijs naar een leven lang leren}

participatie van werkenden. Dit duidt er op dat er op dit punt geen reële keuze is tussen een scholings- en recruteringsoptie.

Bij-en omscholen werkzoekenden en niet-participerenden

In de prognosestudies van het ROA, zoals die gepubliceerd worden in de tweejaarlijkse rapportage $D e$ arbeidsmarkt naar opleiding en beroep tot. . . . (zie bijvoorbeeld ROA, 1999) en in de jaarlijkse RAIL rapporten met betrekking tot Limburgse arbeidsmarkt (zie bijvoorbeeld Diephuis c.s., 2000) hebben we de laatste jaren ook aandacht besteed aan de mogelijke betekenis van de bij- en omscholing van werkzoekenden en niet-participerenden voor het verminderen van de verwachte knelpunten op de arbeidsmarkt. In dit kader kan gesproken worden van "marktconforme" scholingstrajecten. Uitgangspunt hierbij is dat de bij- of omscholing van mensen met een opleidingsachtergrond met ongunstige perspectieven, zich zou moeten richten op verwante opleidingen, waarvoor een goed arbeidsmarktperspectief wordt voorspeld. Daarnaast zullen langdurig werklozen en niet-participerenden die een opleidingsachtergrond hebben die op zich goed in de markt ligt vaak moeten worden bijgeschoold om de in de loop der tijd gegroeide "afstand tot de arbeidsmarkt" te kunnen overbruggen.

Uit de internationale literatuur met betrekking tot de evaluatiestudies van scholingsprogramma's voor moeilijk inzetbare werklozen komt echter vaak naar voren dat de effectiviteit van dergelijke scholingstrajecten doorgaans gering is (zie bijwoorbeeld Schmid c.s., 1996 en Friedlander c.s., 1997), al moet daarbij de kanttekening worden gemaakt dat het Amerikaanse onderzoek zich meestal niet richt op de uitstroomkans naar werk, maar kijkt naar de inkomensverbetering. Uit 


\section{Van tweedekansonderwijs naar een leven lang leren}

een overzichtsstudie van De Koning (1998) komt naar voren dat de scholing van werkzoekenden meer succesvol is wanneer het gericht is op het verminderen van de knelpunten in de personeelsvoorziening waarmee werkgevers kampen. In een artikel naar aanleiding van mijn proefschrift heb ik al eens laten zien dat de scholingsparticipatie van werkzoekenden de mismatch op de arbeidsmarkt doet afnemen (De Grip, 1987b). Over de bijdrage die scholing kan leveren aan het evenwicht tussen de op de arbeidsmarkt gevraagde en aangeboden kwalificaties is echter nog weinig bekend.

Uit de prognosestudies van het ROA komt duidelijk naar voren dat het voor het verminderen van de spanning op de arbeidsmarkt erg belangrijk is om mensen met een VMBO-opleiding "op te scholen" tot op MBO-niveau. Voor de meeste uitvoerende beroepen is tegenwoordig, zoals ik reeds eerder aangaf, minimaal een MBO-opleiding gewenst. Daarnaast wijzen onze laatste prognoses voor de periode tot 2004 ook op het belang van het doorleren van MBO'ers met minder gunstige arbeidsmarktperspectieven voor het verminderen van de verwachte tekorten voor verschillende categorieën HBO'ers. Volgens het Ontwerp Hoger Onderwijs en Onderzoek Plan 2000 zouden met name de in toenemende mate binnen het $\mathrm{HBO}$ van de grond komende "duale opleidingen" een belangrijke rol kunnen spelen bij het opscholen van MBO'ers tot een HBO-niveau. Hierbij gaat het om opleidingen als het Gilde $\mathrm{HBO}$, de MKB route, e.d.

Met name op de arbeidsmarkt voor hoger opgeleiden zullen de knelpunten in de personeelsvoorziening waarmee bedrijven en instellingen kampen echter voor een belangrijk deel moeten worden bestreden door het opscholen van het huidige personeel en het op peil houden van de kwalificaties van het personeel. Deze scholing van werkenden 
is, zoals ik reeds eerder aangaf, een cruciale schakel in het personeelsbeleid gericht op het verminderen van de vroegtijdige arbeidsmarktuitstroom. Uit de Toekomstverkenning arbeidsmarkt en scholing tot 2007 van Lex Borghans c.s. (1998) komt naar voren dat het beperken van de uitstroom van ouderen éên van de meest effectieve mogelijkheden is om het arbeidsaanbod zodanig te vergroten dat veel knelpunten op de arbeidsmarkt worden opgelost.

\section{Welke inzichten biedt de economische theorie?}

Verklaringen voor investeringen in post-initieel onderwijs

Vanuit het basismodel van de human-capital theorie zou men geneigd kunnen zijn te denken dat alle investeringen in menselijk kapitaal in het initieel onderwijs zouden moeten plaatsvinden. Immers, in dat geval zijn de "opportunity costs" het geringst en is de periode dat men profijt trekt van de gevolgde scholing het langst. Een verklaring voor het feit dat niet alle scholingsinvesteringen aan het begin van iemands levensloop plaatsvinden is het probleem dat mensen kunnen ondervinden om hun investeringen in menselijk kapitaal te financieren, omdat het menselijk kapitaal dat men verwerft niet als onderpand kan dienen voor een lening. In navolging van veel eerdere noties van Marshall (1890) wijst Becker (1964, p. 55) op dit belangrijke verschil met andere kapitaalgoederen:

"human-capital is a very illiquid asset - it cannot be sold and is rather poor collateral on loans". 
Vooral voor de lagere inkomensgroepen zal het daardoor vaak moeilijk zijn om scholingsinvesteringen te financieren. Hiermee wordt in feite een verklaring gegeven van de rol van het post-initieel onderwijs als tweedekansonderwijs. Zoals ik reeds aangaf speelt dit financieringsargument momenteel een veel minder belangrijke rol dan in het verleden. Dit zowel vanwege de bestaande studiefinancieringsmogelijkheden, als het in het algemeen hogere welvaartsniveau.

De tweede verklaring die in de literatuur met betrekking tot de allocatie van human capital investeringen over iemands leven te vinden is voor de investeringen in post-initieel onderwijs is het optreden van scholingsveroudering. De in de jaren zeventig door Welch (1970) en Schultz (1975) ontwikkelde economische modellen laten zien dat een snellere veroudering van specifieke kennis en vaardigheden er toe zullen leiden dat mensen aan de ene kant meer in hun initiële opleiding zullen investeren, voor zover het gaat om algemene competenties. Hierbij kan men vooral denken aan kennis op een hoger abstractieniveau en het ontwikkelen van studievaardigheden en een groter probleemoplossend vermogen. Aan de andere kant zullen mensen hun scholingsinvesteringen in specifieke kennis en vaardigheden meer gaan spreiden over hun loopbaan. De modellen van Welch en Schultz geven hiermee een goede verklaring voor twee belangrijke implicaties van de ontwikkelingen die er op dit punt momenteel plaatsvinden.

Borghans en Van Loo (2000) wijzen nog op een derde mogelijke theoretische verklaring voor investeringen in post-initièle scholing: de combinatie van werken en leren is soms de meest efficiënte leerroute. Arrow (1962) wees reeds in de jaren zestig op de betekenis van learning by doing. Het leren is hierbij een nevenproduct van het 
werken in een bepaalde functie. Arrow illustreerde dit proces van "learning-by-doing" met het zogenaamde "Horndal effect". In de Horndal metaalfabrieken in Zweden vond er in 15 jaar geen enkele investering plaats. Toch was er sprake van een jaarlijkse productiviteitsstijging van $2 \%$. Bepaalde vaardigheden kunnen efficiënter tijdens het werk geleerd worden dan in de schoolbanken. Dit argument heeft in feite betrekking op de productie-technologie van menselijk kapitaal en is derhalve ook een centraal aandachtspunt in de onderwijskunde.

\section{Human-capital theorie}

Binnen de human-capital theorie is er, zoals gezegd, van het begin af aan aandacht geweest voor de investeringen in post-initiële scholing. Daarbij gaat de aandacht in navolging van Becker (1962) vooral uit naar de vraag in hoeverre werkgevers en werknemers bereid zijn in algemene of bedrijfsspecifieke scholing te investeren. Wendy Smits en Thorsten Stromback (2000) geven een fraai overzicht van de theorievorming op dit punt, toegespitst op het duaal onderwijs.

De human-capital theorie geeft goede verklaringen voor de onderinvesteringen in algemene scholing. Dat wil zeggen, scholing die de marktwaarde van mensen verhoogt. Werknemers zullen vaak niet bereid zijn om in verdere scholing te investeren, omdat ze de trainingskosten niet kunnen financieren en ook het risico lopen dat het verworven human capital zijn waarde verliest door verschuivingen in de vraag naar de verworven kwalificaties (zie bijvoorbeeld Greenhalgh, 1999 en Stevens, 1999).Werkgevers lopen het risico dat werknemers die men heeft opgeleid worden weggekocht door concurrenten die zelf niet investeren in de scholing van hun personeel voor zover dit hun marktwaarde verhoogt. Dit wordt, zoals gezegd, doorgaans 


\section{Van tweedekansonderwijs naar een leven lang leren}

aangeduid als het "poaching risico". Stevens (1994) introduceert in dit verband het begrip "transferable training". Dit is training die ook voor andere bedrijven relevant is, maar vanwege imperfecte concurrentie niet leidt tot een loon dat gelijk is aan de marginale productiviteit. Hierdoor ontstaat er een extern effect, waardoor bedrijven vanwege het verlooprisico minder zullen investeren in deze scholing van hun werknemers, dan in het geval dat ze zeker waren dat ze zelf alle baten van deze scholingsinvesteringen zouden kunnen toe-eigenen.

Acemoglou en Pischke (1999) laten zien dat de bereidheid van werkgevers om in de algemene scholing van hun werknemers te investeren samenhangt met de marktvorm. Wanneer instituties er voor zorgen dat de loonverschillen tussen laag en hoog opgeleiden minder groot zijn dan bij een volledig concurrerende markt, kunnen werkgevers zich immers een groter deel van de productiviteitsstijging die behaald wordt door het volgen van scholing toe-eigenen.

De economische theorievorming verklaart ook de onderinvesteringen in bedrijfsspecifieke scholing. Hier is er sprake van wat wordt aangeduid als een "hold-up" probleem. Werkgevers investeren onvoldoende in bedrijfsspecifieke scholing, omdat het rendement van deze investeringen afhankelijk is van de bereidheid van het personeel om bij hen te blijven werken. Wanneer een werkgever dergelijke investeringen doet geeft dit de werknemers derhalve in de loononderhandelingen een machtsmiddel in handen, omdat ze kunnen dreigen met hun vertrek waardoor de eerder door de werkgever betaalde investeringen in bedrijfsspecifieke scholing verloren gaan (Teulings en Hartog, 1998). 


\section{Assignmenttheorie}

De assignmenttheorie biedt, zoals ik reeds eerder aangaf, een theoretisch raamwerk voor het analyseren van het allocatieproces op de arbeidsmarkt (zie bijvoorbeeld Macdonald, 1980, Teulings, 1995, Van Eijs en Heijke, 2000 en Borghans en De Grip, 2000). Hierbij gaat het om de allocatie van mensen met uiteenlopende kwalificaties over functies met uiteenlopende kwalificatie-eisen. De assignmenttheorie benadrukt daarbij de comparatieve voordelen die mensen die over bepaalde competenties beschikken in bepaalde functies hebben. De productiviteit van werkenden is daardoor zowel afhankelijk van hun opleidingsachtergrond als van de functie die men uitoefent. Dit biedt ook een theoretisch raamwerk voor het analyseren van de betekenis van aanvullende scholing voor het overbruggen van de kloof tussen de voor een functie vereiste kwalificaties en de kwalificaties waarover degene die voor deze functie is aangetrokken beschikt (Barron c.s., 1989).

De assignment literatuur richt zich overigens vrijwel alleen op de allocatie van werkenden met een verschillend opleidingsniveau over de verschillende functieniveaus (zie Hartog, 1992). In een recent paper van Arnaud Dupuy en mijzelf gaan we in op de substitutie van werkenden met een $\mathrm{MBO}$-opleiding, die verschillen qua opleidingsrichting. Hieruit komt onder andere naar voren dat er op de arbeidsmarkt ook sprake is van indirecte reallocatie routes (zie Dupuy en Borghans, 2000). Wanneer er bijvoorbeeld sprake is van een tekort aan technisch opgeleiden, worden voor bepaalde functies waarvoor bij voorkeur technisch opgeleiden worden geworven, mensen met een algemene of economisch administratieve opleidingsachtergrond gerekruteerd. De vacante functies in het economisch-administratieve be- 
roependomein worden vervolgens weer opgevuld door mensen met een verzorgende of dienstverlenende opleiding (Dupuy en De Grip, 2000).

Institutionele economische theorie

In de institutionele economische theorie bestaat er ook een aantal belangrijke theoretische invalshoeken voor de analyse van de investeringen in post-initiële scholing. In de baanconcurrentietheorie van Thurow (1975) wordt de initiële opleiding die iemand heeft gevolgd slechts gezien als een selectiemiddel voor werkgevers om de best "trainbare" arbeidskrachten te selecteren. Daarbij wordt verondersteld dat de meeste voor een adequate beroepsuitoefening vereiste kwalificaties in de beroepspraktijk zelf worden aangeleerd.

In de arbeidsmarktsegmentatietheorie wordt een expliciet onderscheid gemaakt tussen de betekenis van scholing op de verschillende segmenten van de arbeidsmarkt. Hierbij wordt meestal een onderscheid gemaakt tussen de bedrijfsinterne arbeidsmarkt, de vakdeelmarkt en de zogenaamde "secundaire" arbeidsmarkt (zie bijvoorbeeld De Grip, 1985). Op de bedrijfsinterne arbeidsmarkt speelt scholing een centrale rol voor iemands loopbaan binnen het bedrijf. Hierbij gaat het met name om bedrijfsspecifieke scholing. Op de vakdeelmarkt zijn er daarentegen veel minder mogelijkheden om door het volgen van loopbaangerichte scholing door te groeien naar een hoger functieniveau. Op de secundaire arbeidsmarkt zal er ook weinig worden geïnvesteerd in de post-initiële scholing van degenen die op dit segment van de arbeidsmarkt werkzaam zijn (zie bijvoorbeeld Osterman, 1982). Werkgevers beschouwen degenen die in deze secundaire functies werken slechts als tijdelijk met het bedrijf 
verbonden personeel. Ook de betrokkenen zelf hebben slechts een marginale binding met het werk dat ze uitoefenen. Hierdoor zijn er bij beide partijen weinig prikkels om in aanvullende scholing te investeren.

Men kan zich echter afvragen of het karakter van het secundaire segment van de arbeidsmarkt de afgelopen decennia niet veranderd is. Het is meer een voorportaal geworden waarin er een selectie plaatsvindt woor de functies op de bedrijfsinterne arbeidsmarkten. Intreders op de arbeidsmarkt worden vaak eerst tijdelijke contracten aangeboden. Daarnaast selecteren bedrijwen de beste krachten uit de uitzendkrachten die ze hebben ingeleend. Door dit veranderde karakter van de secundaire arbeidsmarkt neemt het belang van het volgen van aanvullende opleidingen met name voor de betrokkenen zelf sterk toe. Door het volgen van aanvullende scholing kan men zich op den duur kwalificeren voor een functie in het primaire segment van de arbeidsmarkt. Dit geeft aan hoe belangrijk het volgen van post-initiële scholing is geworden voor intreders op de arbeidsmarkt die niet meteen na het verlaten van het initieel onderwijs een goede positie weten te verwerven. Dit laatste blijkt ook uit studies van Lynch (1993) en uit onderzoek dat ik samen met Ron Dekker en Hans Heijke heb gedaan met betrekking tot de Nederlandse arbeidsmarkt (Dekker c.s., 1996).

Het onderzoek naar de betekenis van het post-initieel onderwijs in relatie tot de veranderingen in de op de arbeidsmarkt gevraagde competenties is echter bepaald niet het exclusieve domein van de economische wetenschap. Daardoor zijn er interessante raakvlakken met andere disciplines. Ik denk daarbij met name aan de vakgebieden van het human resource management en de onderwijskunde. 


\section{Human resource management: de employability van werkenden}

In de human resource management (HRM) literatuur wordt de ontwikkeling van het "menselijk potentieel" gezien als een strategische factor voor de overlevingskansen van een organisatie (zie bijvoorbeeld Fombrun c.s., 1984). Het personeelsontwikkelingsbeleid, oftewell het human resource development (HRD) neemt een centrale plaats in binnen de HRM literatuur. Deze literatuur richt zich op de relatie tussen bedrijfsprocessen en de vereiste competenties en de op basis daarvan vereiste competentie-ontwikkeling van het personeel (zie bijvoorbeeld Spencer en Spencer, 1993). Een competentie wordt daarbij gezien als een handelingsbekwaamheid: het vermogen om effectief te presteren in een bepaalde situatie. Hierbij gaat het om een combinatie van kennis, ervaring en inzicht ("expertise") en het vereiste gedrag in een bepaalde situatie (Hoekstra en Van Sluijs, 1999).

Terwijl er vanuit het economische vakgebied meer aandacht komt voor de scholing van werkenden, worden er vanuit de HRD hoek juist meer twijfels geuit over de betekenis van het post-initiële onderwijs in de vorm van formele opleidingen. Zo stelt Kessels, hoogleraar HRD aan de Universiteit Twente en de Universiteit Leiden, in een interview in de NRC ( 9 november 1999):

"Ik zeg dat de leerprocessen die dagelijks in de werksituatie plaatsvinden vele malen sterker en effectiever zijn dan cursussen die apart en op een centraal niveau zijn georganiseerd..... Als werksituatie en 
cursus niet helemaal op elkaar aansluiten, legt de cursusrealiteit het gemakkelijk af tegen wat er op het werk gebeurt".

Anders gezegd, opleidingen moeten worden afgestemd op de behoefte die men heeft op de werkplek. Dit pleit voor het "on-the-job leren" dat vaak directer aansluit op de specifieke leerbehoeften die men heeft. Dit sluit aan bij de conclusie uit het eerder genoemde onderzoek van Lex Borghans e.a. onder de servicemedewerkers van $A B P / U S Z O$ dat werknemers zelf meer initiatieven voor hun competentieontwikkeling zouden moeten kunnen nemen.

\section{Employability}

De HRM literatuur plaatst de scholingsproblematiek bovendien in het bredere kader van de employability van werkenden (zie bijvoorbeeld Waterman c.s., 1994 en Thijssen, 1996). Employability wordt daarbij met name geïnterpreteerd als een brede inzetbaarheid van werkenden. Deze brede inzetbaarheid is volgens de HRD-literatuur zowel in het belang van de werkgever als de werknemer, omdat "levenslange dienstverbanden" plaatsmaken voor wat men wel aanduidt als de "protean career": de veelvormige, veranderlijke loopbaan (zie bijvoorbeeld Hall en Moss, 1998).

Employability wordt vaak kortweg gedefinieerd als "het vermogen van mensen om werk te krijgen en te houden" (zie bijvoorbeeld Ministerie van OC\&W, 1998 en De Grip en Sanders, 2000). In de HRD literatuur is employability uitgegroeid tot een containerbegrip. Langzamerhand lijkt echter het accent te verschuiven naar de verantwoordelijkheid van werknemers voor hun eigen loopbaanontwikkeling (zie bijvoorbeeld Bloch en Bates, 1995). De werknemer wordt daarbij gezien als een zelfredzame persoon die de zekerheid 
wan een baan inruilt voor de zekerheid van werk. Werkenden verkrijgen deze zekerheid door er voortdurend voor te zorgen dat zij over een voor de arbeidsmarkt aantrekkelijk kennis en vaardighedenpakket beschikken.

De afgelopen jaren heb ik in een aantal publicaties tezamen met Jasper van Loo en Jos Sanders (zie bijvoorbeeld De Grip c.s., 1999 en De Grip en Sanders, 2000) geprobeerd de employability van werkenden en werkzoekenden meer expliciet in een vraag-aanbod raamwerk te plaatsen. Immers, de mate waarin iemand breed inzetbaar moet zijn en moet kunnen inspelen op veranderingen in de aard van het werk, is sterk afhankelijk van de bedrijfssector of de beroepsgroep waarin men werkzaam is. Zo zijn bijvoorbeeld de veranderingen in de aard van het werk in de banksector vanwege technologische en organisatorische vernieuwingen veel omvangrijker dan in de bouwsector (zie De Grip c.s., 1999).

In dit kader is door ons in opdracht van het Ministerie van Sociale Zaken en Werkgelegenheid een Sectorale Employability Index (SEI) ontwikkeld. Deze index belicht een drietal facetten die bepalend zijn voor de employability van werkenden in de desbetreffende sector:

- vraag: de behoefte aan emplooibaar personeel;

- aanbod: de daadwerkelijke inzetbaarheid;

- instituties: de effectueringcondities.

Ik zal achtereenvolgens op deze drie facetten van de employability van werkenden ingaan.

De behoefte aan employability is door ons afhankelijk gesteld van een viertal factoren. Technologische ontwikkelingen, en dan met name 
ontwikkelingen in de informatie- en communicatietechnologie, kunnen ertoe leiden dat de kwalificaties van werknemers niet langer toereikend zijn om hun werk naar behoren te kunnen uitwoeren. Ook organisatorische veranderingen kunnen, zoals ik reeds eerder heb aangegeven, een oorzaak zijn van kwalificatieveroudering. Daarnaast bepalen economische en demografische ontwikkelingen de behoefte aan employability. Zo doet de toenemende concurrentie op diverse markten een beroep op het aanpassingsvermogen van de werknemers in verschillende bedrijfstakken. Daarnaast wordt het door de vergrijzing en ontgroening van de beroepsbevolking in veel bedrijfssectoren noodzakelijk om oudere werknemers langer in dienst te houden.

\section{Figuur 3}

Sectorale Employability Index.

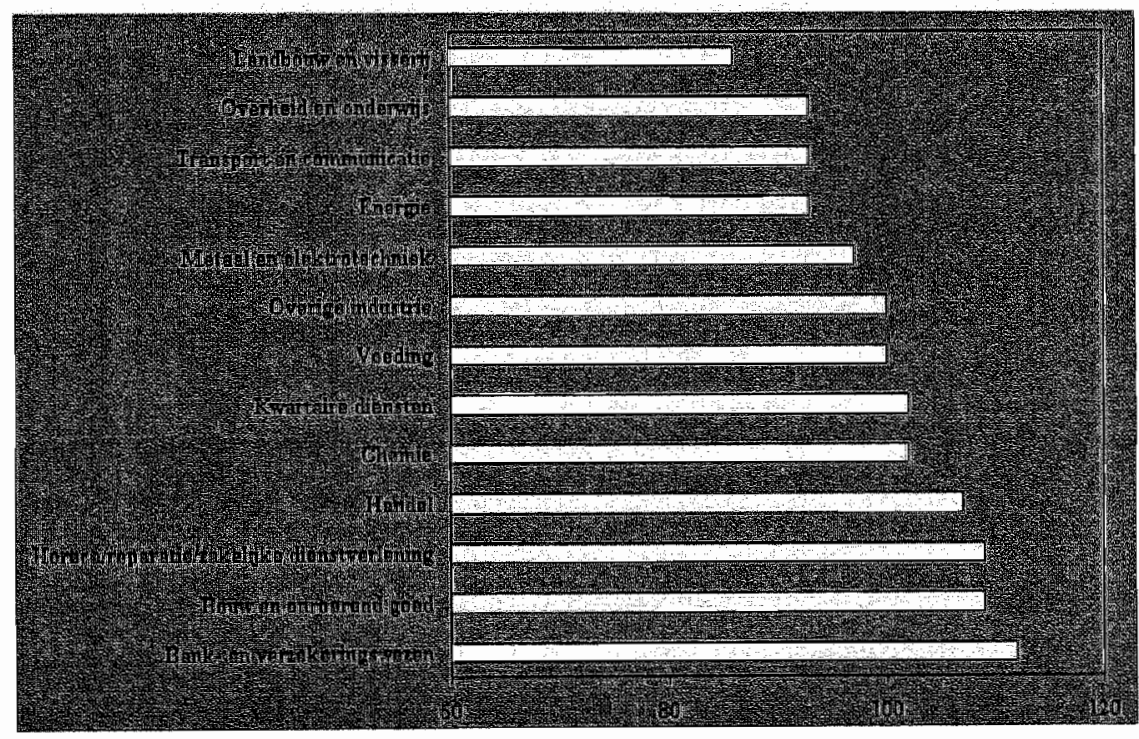


De behoefte aan emplooibaar personeel op basis de vier genoemde ontwikkelingen is het grootst in de chemie, de energie-sector, de metaal en elektrotechniek en de sector overheid en onderwijs. In de handel en de bouwsector is de employability behoefte daarentegen veel lager.

De inzetbaarheid van werknemers wordt bepaald door hun vermogens en hun bereidheid om employable te zijn. De bereidheid om employable te zijn heeft betrekking op de bereidheid zich bij te scholen, van functie te veranderen en al dan niet tijdelijk werk te doen dat niet tot de eigen functie behoort. Het employability-vermogen heeft betrekking op het leervermogen, het vermogen om van functie te veranderen en het vermogen om breed inzetbaar te zijn. Op dit punt moet echter worden beseft dat er sprake kan zijn van een trade-off tussen een brede inzetbaarheid van werkenden en een hoge productiviteit in een bepaald vakgebied. Een grotere employability hoeft dus niet gepaard te gaan met hogere verdiensten. Dit laatste wordt bevestigd in een recent artikel van Groot en Maassen van den Brink (2000).

Bovendien, als werknemers wel employable zijn maar niet de kans krijgen om daar iets mee te doen, zullen zowel werknemers als bedrijven weinig aan die employability hebben. Daarom is het ook van bellang te kijken naar de mogelijkheden die de werknemers worden geboden om hun employability te manifesteren. Thijssen (1997) bestempelde dit als de "effectueringscondities". In feite gaat het hier om de instituties die de ontwikkeling van de employability van de werkenden in een bepaalde bedrijfssector faciliteren. Deze zijn door ons geindiceerd op basis van de scholingsinspanningen in de bedrijfssector. Daarnaast hebben we gekeken naar de verwachte werkgelegenheidsontwikkeling voor de desbetreffende sector. Dit laatste is 


\section{Van tweedekansonderwijs naar een leven lang leren}

immers in belangrijke mate bepalend voor de doorgroeimogelijkheden die de werknemers in de desbetreffende sector worden geboden.

Wanneer de behoefte aan employability gerelateerd wordt aan de feitelijke inzetbaarheid en de effectueringcondities, kan een uitspraak worden gedaan over de employability van de werkenden in de verschillende bedrijfssectoren. Uit de door ons geconstrueerde Sectorale Employability Index blijkt dat het bank- en verzekeringswezen op het vlak van de employability van de werknemers het beste scoort. Deze gunstige positie heeft de sector te danken aan de goede inzetbaarheid van het personeel en de goede mogelijkheden die hen worden geboden om hun employability tot uiting te laten komen. Het slechtst scoort de landbouw en visserij, waar zowel de feitelijke inzetbaarheid van de werkenden als de effectueringcondities sterk achter blijven. Ook de sector overheid en onderwijs heeft een verontrustend lage score op de employability index. In deze sector is dit eveneens het gevolg van de geringe inzetbaarheid van de werkenden en de achterblijvende ontplooiingsmogelijkheden.

\section{Personnel economics}

De human resource management literatuur heeft een sterk beschrijvend karakter en is vaak casuistisch. In zijn in 1995 verschenen boek Personnel Economics plaatst Lazear (1995) het HRM-beleid van arbeidsorganisaties in een meer systematisch economisch kader. Daarbij worden specifiek HRM-concepten ingepast in een economische analyse. Deze "Personnel Economics" kan denk ik een belangrijke impuls geven aan de verdere ontwikkeling van de theorievorming met betrekking tot de training van werkenden. 
Zo analyseren Lindbeck en Snower (2000) vanuit een micro-economische invalshoek de betekenis van "multi-task learning" en "intertask learning" voor ondernemingen die in het productieproces in toenemende mate de nadruk leggen op een "platte" organisatie. Daarbij wordt gewerkt in klantgerichte teams, waarvan de teamleden in staat moeten zijn uiteenlopende activiteiten te verrichten. Multitask learning heeft betrekking op het moeten verwerven van verschillende skills. Inter-task learning verbreedt in feite Arrow's learningby-doing concept. Er is sprake van inter-task learning als iemand door het verrichten van bepaalde werkzaamheden ook competenties verwerft die hem of haar in staat stellen andere taken te verrichten.

Lindbeck en Snower noemen daarbij voorbeelden als:

- het gebruiken van kennis die iemand verwerft in de marketing bij het ontwerpen van nieuwe producten;

- kennis verworven in het productieproces die kan worden gebruikt bij het scholen van nieuwe arbeidskrachten.

\section{Onderwijskunde: de betekenis van brede opleidingen en "sleutelkwalificaties"}

Het vakgebied van mijn leerstoel heeft vanzelfsprekend ook een duidelijk raakvlak met het onderzoeksterrein van de onderwijskunde. Daarbij gaat het zowel om inzichten in de processen van kwalificatieverwerving ("de productietechnologie"), als om de betekenis van bepaalde kwalificaties voor het handhaven van iemands positie op de arbeidsmarkt. Hierbij gaat het ook om vraagstukken als de gewenste "breedte" van een opleiding (zie bijvoorbeeld Nijhof, 
1998) en de betekenis van "sleutelkwalificaties" om in te kunnen spelen op veranderende kwalificatie-eisen vanwege technologische vernieuwingen, organisatorische veranderingen en andere ontwikkelingen op de arbeidsmarkt (zie bijvoorbeeld Van Zolingen, 1995, Onstenk, 1997 en Nijhof en Streumer, 1997).

\section{De "breedte" van een opleiding}

Hoewel het nog lang niet altijd duidelijk is hoe de verschillende kenmerken van het curriculum van de initiële opleiding van invloed zijn op de verwerving van kennis en vaardigheden, bepalen zij de competenties waarmee iemand de arbeidsmarkt betreedt (Nijhof, 1998). Als men het in de onderwijskunde heeft over een brede opleiding slaat dit op de input van het onderwijs: de breedte van het curriculum. Dit is een belangrijk verschilpunt met het onderscheid tussen algemene en specifieke scholing, zoals dit in de economische human capital theorie wordt gemaakt. In de human-capital theorie heeft specifiek menselijk kapitaal betrekking op kennis en vaardigheden die alleen voor het werk in een bepaald bedrijf tot een hogere productiviteit leiden, terwijl algemeen menselijk kapitaal ook iemands externe waarde op de arbeidsmarkt vergroot. De breedte van de opleiding heeft hier dus betrekking op de output van het onderwijs: de bruikbaarheid van de verworven kwalificaties op de arbeidsmarkt.

Dit verschilpunt tussen de onderwijskundige en economische betekenis van de breedte van een opleiding is van groot belang voor het beoordelen van de betekenis van een bepaalde opleiding op de arbeidsmarkt (Borghans en De Grip, 1999). Vanuit een arbeidsmarkteconomische invalshoek moet de breedte van een opleiding worden beoordeeld op basis van een tweetal invalshoeken. 
In de eerste plaats gaat het hierbij om de omvang en diversiteit van het beroependomein waarin men met de desbetreffende opleiding kan gaan werken. Men spreekt in dit verband wel van de "option value of education" (Dothan en Williams, 1981). Iemand die een opleiding volgt die toegang verschaft tot meerdere beroepen, stelt als het ware de beroepskeuze nog uit tot het moment waarop hij of zij de arbeidsmarkt betreedt. Hierdoor neemt het risico voor onverwachte verschuivingen op de arbeidsmarkt enigszins af. Dit argument is ook terug te vinden in de zgn. "reële optie theorie" waarin het investeringsgedrag van ondernemers centraal staat (Dixit en Pindyck, 1994). Deze reële optie theorie geeft aan dat het rendabel kan zijn een investering met een positief rendement nog niet te doen bij onzekerheid over het toekomstig rendement.

In het initiële beroepsonderwijs zijn er verschillende voorbeelden van opleidingen met een breed curriculum, die men vanuit dit arbeidsmarktoogpunt als gespecialiseerde opleidingen kan beschouwen. Hierbij kan men bijvoorbeeld denken aan de opleidingen milieukunde en toerisme en recreatie. Vanuit arbeidsmarktoogpunt hebben de schoolverlaters van de opleiding toerisme en recreatie bijvoorbeeld een veel sterkere specialisatie dan degenen met een opleiding commerciële economie, ondanks het feit dat ze met meerdere vakgebieden in aanraking zijn geweest. Omgekeerd zijn er monodisciplinaire opleidingen, zoals bijvoorbeeld een universitaire economie opleiding, waarvan de afgestudeerden in een breed beroependomein terecht kunnen.

Ook bij het analyseren van de breedte van de scholing van werkenden en werkzoekenden, dient primair gekeken te worden naar de implica- 
ties van de gevolgde scholing voor iemands uitwijkmogelijkheden op de arbeidsmarkt.

In de tweede plaats heeft de breedte van een opleiding vanuit een arbeidsmarkteconomische optiek betrekking op de mate waarin iemand is opgewassen tegen veranderingen in de aard van het werk. Hierbij gaat het om de vraag in hoeverre de opleiding die iemand heeft gevolgd het risico op kwalificatieveroudering vermindert.

\section{Sleutelkwalificaties}

Op dit punt kunnen onderwijskundige inzichten van grote waarde zijn voor een arbeidsmarkteconomische invalshoek. Daarbij kan met name worden gedacht aan het reeds genoemde onderwijskundige onderzoek gericht op het traceren van de "sleutelkwalificaties" voor een bepaald beroepsveld. Hierbij gaat het volgens Van Zolingen (1995, p. 117) om de "kennis, inzicht, vaardigheden en houdingen die behoren tot de duurzame kern van een beroep of een groep verwante functies". . Deze kernproblemen voor een bepaald beroepsveld moeten dan ook richtinggevend zijn voor de inhoud van beroepsopleidingen. Dit betekent volgens Onstenk (1997) dat het beroepsonderwijs leerlingen beroepsmatige probleemoplossingvaardigheden moet bijbrengen: het kunnen omgaan met problemen, diagnoses kunnen stellen, plannen en systematisch leren werken, het leren optimaal te werken in verschillende situaties, het leren samenwerken in een team, e.d. Deze sleutelkwalificaties spelen ongetwijfeld ook een belangrijke rol bij het eerder genoemde "multi-task learning" dat Lindbeck en Snower een prominente rol toebedelen in het leerproces van de mensen die werkzaam zijn in een moderne arbeidsorganisatie. 


\section{Van tweedekansonderwijs naar een leven lang leren}

Vanuit de onderwijskunde wordt ook gewezen op de competenties die van belang zijn voor het leren op de werkplek. Het leren op het werk is in grote mate zelfgestuurd leren. Dit betekent dat vooral de leervaardigheden van de werknemers en hun motivatie om te leren van groot belang zijn voor het leerproces (zie bijvoorbeeld Simons, 1990 en Onstenk, 1997). Het leervermogen van werkenden is over het algemeen groter naarmate men een bredere opleidingsachtergrond heeft en beschikt over een aantal cruciale steutelkwalificaties: het kunnen omgaan met problemen, diagnoses kunnen stellen, abstractievermogen e.d.

Bovendien is ook het leren op het werk een zichzelf versterkend proces. In het leerproces nemen de competenties van iemand toe, die op hun beurt het verder leren en ontwikkelen weer kunnen bevorderen (Onstenk, 1997). Thijssen (1996) wijst er op dat dit niet altijd het geval hoeft te zijn. Weliswaar doen werkenden in hun loopbaan steeds meer ervaring op, maar daarbij is er vaak sprake van een toenemende versmalling van deze expertise; de zogenaamde "ervaringsconcentratie". Dit wijst ook op het belang van de mogelijkheden die mensen geboden worden zich tijdens hun werk verder te ontwikkelen. Men spreekt hier over het belang van een "leerrijke werkomgeving". Dit sluit aan bij eerder werk van Sherwin Rosen (1972) dat de arbeidsmarkt analyseert als een impliciete markt voor leermogelijkheden. Sicherman en Galor (1990) werken dit verder uit in hun "career mobility" model, waarin werknemers in bepaalde minder goed betalende functies competenties verwerven die hun kans om door te stromen naar een hogere functie vergroot (zie ook Lazear, 1995). 


\section{Wat betekent "een leven lang leren" voor de universiteit?}

In het vorig jaar door de SER (1999) uitgebrachte Advies HOOP 2000 wordt er uitdrukkelijk op gewezen dat het Hoger Onderwijs niet alleen de taak heeft om voldoende goed geschoolde mensen op te leiden in het licht van de internationale positionering van de Nederlandse economie als een "kennissamenleving". Het Hoger Onderwijs dient bovendien zorg te dragen voor het onderhouden van de kwalificaties van de hoger opgeleide beroepsbevolking, die geconfronteerd wordt met een continu veranderende omgeving. Om deze rol te kunnen vervullen dient het Hoger Onderwijs zich volgens de SER zowel inhoudelijk als organisatorisch te richten op de postinitiële scholing van werkenden en werkzoekenden. Daarbij kan het overigens zowel gaan om het verhogen van het opleidingsniveau van de beroepsbevolking, als om het kennisonderhoud van mensen met een universitaire opleidingsachtergrond.

Zoals ik reeds eerder heb aangegeven dient de basis voor het "een leven lang kunnen leren" echter in het initieel onderwijs te worden gelegd. Daarbij gaat het in de eerste plaats om de "optiewaarde" van de initiêle opleiding, in de zin van een vanuit arbeidsmarktoptiek voldoende brede opleiding. In de tweede plaats gaat het om het verwerven van de sleutelkwalificaties, waarover de werkenden in een kennisintensieve samenleving moeten beschikken. In het begin van mijn rede noemde ik reeds de zes "key skills" die de Britse National Skills Task Force op dit punt naar voren schuift. 
Dit brengt me op de betekenis van het probleem gestururd onderwijs (PGO). Het grote belang dat in de kenniseconomie gehecht wordt aan het probleem oplossend vermogen van werkenden, hun leervermogen, communicatieve vaardigheden en het goed kunnen samenwerken met anderen geeft aan dat wat ik zou willen aanduiden als de kerncompetentie van de Universiteit Maastricht, het probleem gestuurd onderwijs (PGO), een belangrijke rol kan vervullen in de kenniseconomie. Het $\mathrm{PGO}$ is gericht op de sleutelkwalificaties die vereist zijn om adequaat te kunnen functioneren in een moderne arbeidsorganisatie. Bovendien zou het de weerbaarheid van mensen tegen kwalificatieveroudering vanwege technische en organisatorische ontwikkelingen kunnen vergroten. Naar dit alles is echter nog opmerkelijk weinig onderzoek gedaan.

Veel van de genoemde key-skills kunnen niet als vak worden onderwezen. Bovendien zijn deze vaardigheden sterk gerelateerd aan de in een bepaald functiegebied vereiste vakspecifieke competenties. Juist het $\mathrm{PGO}$ biedt in principe de mogelijkheden deze relatie te leggen. De combinatie van disciplinaire kennis en de genoemde keyskills lijkt als het ware de nieuwe verschijningsvorm van de "academische vorming" waaraan kenniswerkers behoefte hebben. Dit verklaart ongetwijfeld ook de onstuitbare diffusie van het PGO in het Nederlandse onderwijs.

De start van de nieuwe opleiding onderwijswetenschappen aan deze whiversiteit kan op dit punt een zeer waardevolle stap zijn om de maatschappelijke betekenis van de Universiteit Maastricht te vergroter. Met name ook ondat de nienwe opleiding onderwisswetenschappen een duidelijk accent legt op het post-initiete onderwijs. Daarbij gaat het zowel om de professionele ontwikkeling van werkenden, als 
om het afstandsonderwijs door middel van "elektronische leeromgevingen". Dit "E-learning" is van groot belang voor het bereiken van de nieuwe doelgroepen van het hoger onderwijs.

Van een elektronische leeromgeving is sprake wanneer op elektronische wijze diverse delen van het onderwijsproces worden aangeboden of ondersteund. Daarbij gaat het niet alleen om het aanbieden van leerstof via de computer, maar ook om de communicatie met de docent en medestudenten, het maken van groepsopdrachten, feedback, het bijhouden van de voortgang, e.d. (Gelderblom en De Koning, 2000). Een te sterke focus op ICT als oplossing voor scholingsvraagstukken moet daarbij echter worden vermeden (zie ook Van den Dool c.s., 1999 en De Grip en Van der Velden, 1999). De meerwaarde van afstandsonderwijs zal immers in belangrijke mate bepaald worden door het didactisch concept waarin het docent onafhankelijk leren centraal staat en de mogelijkheden die werkenden worden geboden om precies datgene te leren waaraan ze behoefte hebben. Ook hier gaat het dus primair om de curriculumtechnologie. De combinatie van het tot een kerncompetentie van de Universiteit Maastricht uitgegroeide probleem gestuurd onderwijs met de expertisevorming met betrekking tot de curriculumontwikkeling voor het afstandsonderwijs zou de universiteit een plaats kunnen geven in het hart van de kenniseconomie.

Ook meer in het algemeen zal de ontwikkeling van de samenleving als een kenniseconomie van grote betekenis kunnen zijn voor de universitaire organisatie. Interessant is in dit verband dat men het afgelopen decennium steeds meer oog heeft gekregen voor "de ondernemende universiteil". Het idee van de ondernemende universiteit is niet alleen illustratief voor het feit dat bedrijfseconomische principes 
een steeds grotere rol zijn gaan spelen in de overheidssector en de niet-commerciële dienstverlening. Het bedrijf is in feite ook uitgegroeid tot het "rolmodel" voor de universiteit.

De kenniseconomie zou op dit punt het culturele tij wel eens kunnen keren. Michael Porter (1997), een vooraanstaande autoriteit op het gebied van concurrentiestrategieën van bedrijven en landen, brengt dit als volgt onder woorden:

"De bedrijven die succesvol worden en blijven zijn de bedrijven die snel kunnen leren, die het geleerde kunnen opnemen en nieuwe inzichten kunnen ontwikkelen. Ik vermoed dat bedrijven veel meer dan in het verleden moeten gaan lijken op universiteiten."

Met andere woorden: de noodzaak tot het "een leven lang leren" van de werkenden in de kenniseconomie maakt de universiteit tot het "rolmodel" voor het bedrijfsleven. Zo ontstaan er binnen grote bedrijven "bedrijfsacademies" en worden er elektronische leeromgevingen opgezet, zoals bijwoorbeeld de "Virtuele ING Leeromgeving" van de ING Business school.

Academische competenties vormen daarbij de kern van een zich breed ontwikkelende kennismaatschappij. Kessels (2000) spreekt in dit verband al van de academische leerplekken buiten het universitair onderwijs. In de kenniseconomie verliest de universiteit ook haar monopolie met betrekking tot de kennisontwikkeling en -overdracht. Dit laatste is vanzelfsprekend ook niet zonder betekenis voor de ondernemende universiteit. De universiteit dient zich te positioneren als de meest krachtige leeromgeving in de kennisintensieve samenleving. Dit benadrukt voor de universitaire organisatie de urgentie van 
het besef dat de onderzoekende en docerende kenniswerkers het hart van de zaak vormen.

\section{Wat betekent het toenemende belang van post- initiële scholing voor het overheidsbeleid?}

De veranderende relatie tussen onderwijs en arbeidsmarkt in een kennissamenleving met een toenemende betekenis van het postinitieel onderwijs en het toenemende belang van een adequate afstemming tussen het initiële en het post-initiële onderwijs hebben vanzelfsprekend ook grote gevolgen voor het overheidsbeleid. Aanvankelijk werd het leren van werkenden vooral gezien als een verantwoordelijkheid van de sociale partners, terwijl de Arbeidsvoorzieningsorganisatie de verantwoordelijkheid heeft voor de scholing van werklozen. De rol van de overheid beperkte zich daardoor tot de bekostiging van het initiële onderwijs (De Vijlder, 2000).

Als de investeringen in het volgen van post-initieel onderwijs worden overgelaten aan de markt bestaan er, zoals ik reeds heb aangegeven, echter risico's tot een onderinvestering in menselijk kapitaal. Bovendien zullen bepaalde groepen - oudere werknemers, deeltijders, mensen met een tijdelijke baan - relatief weinig in scholingsactiviteiten participeren. De in een groot aantal bedrijfssectoren in ons land opgezette Opleidings- en Ontwikkelingsfondsen ("O\&O fondsen") hebben de afgelopen jaren echter een belangrijke bijdrage geleverd aan het stimuleren van de scholing van werkenden. Door het opleggen van heffingen en het verstrekken van subsidies verminderen deze 
O\&O fondsen het "marktfalen" met betrekking tot de post-initièle scholing van werkenden.

Echter, de O\&O fondsen richten zich louter op de binnen een bedrijfssector relevante scholingsactiviteiten. Wanneer werkenden vanwege het verouderen van hun kwalificaties zich niet langer kunnen handhaven in hun huidige baan, kan het noodzakelijk zijn hen om te scholen naar werk in een andere sector. Op de behoefte aan een dergelijke omscholing zijn de $O \& O$ fondsen niet gericht. Er ontbreekt daardoor een maatschappelijke infrastructuur die gericht is op het financieren van sectoroverstijgende scholing. Samenwerking tussen $\mathrm{O} \& \mathrm{O}$ fondsen uit verschillende bedrijfstakken zou omscholingsactiviteiten die de intersectorale mobiliteit bevorderen sterk kunnen stimuleren. Dit is van groot belang voor mensen die het risico lopen hun huidige functie te verliezen en geen perspectief hebben op een andere functie binnen de bedrijfstak waarin zij werkzaam zijn.

Mede gestimuleerd door Europese subsidieprogramma's als het voormalige ESF-4 is ook de rijksoverheid in toenemende mate een bijdrage gaan leveren aan de financiering van de bij- en omscholing van werkenden. Daarnaast worden er veel middelen uitgegeven aan de bij- en omscholing van werklozen, de reïntegratie van arbeidsgehandicapten, e.d. In de begin dit jaar gepubliceerde interdepartementale beleidsnota In Goede Banen wordt ook de gedachte uitgesproken elk individu een wettelijk recht en/of een fiscale stimulans te geven op een periodiek assesment van de eigen competenties. De idlee hierbij is dat deze EVC's zullen leiden tot meer maatwerk in de aanvullende opleidingen die men gaat volgen. Dit zal naar verwachting leiden tot een grotere vraag naar "just-in-place" en "just-in-time" 
opleidingen, een efficiënte inzet van scholing en een flexibilisering van het onderwijs (Ministerie van SZW, 2000).

Ook aan de aanbodkant van de markt voor post-initiële scholing wordt de betrokkenheid van de overheid langs directe of indirecte weg groter. De door de overheid bekostigde onderwijsinstellingen begeven zich steeds meer op de markt voor het post-initieel onderwijs. De ROC's verzorgen in opdracht van Arbeidsvoorziening een groot aantal opleidingen gericht op de bij- en omscholing van werklozen. Daarnaast verzorgen de ROC's, Hogescholen en universiteiten ook steeds vaker de zogenaamde "opscholing" van het personeel van grote bedrijven. Ook verzorgen met name de Hogescholen steeds meer "duale opleidingen" in samenwerking met het bedrijfsleven. Aan de andere kant raken de commerciële aanbieders op de markt van het post-initieel onderwijs steeds meer vervlochten met het traditioneel door de overheid bekostigde initiële onderwijs. Zo heeft het LOI een eigen Hogeschool opgericht. Door de te verwachten toename van het belang van het afstandsonderwijs door middel van elektronische leeromgevingen zal de markt voor de commerciële en niet-commerciële aanbieders van onderwijs in de toekomst nog verder vervlochten raken.

Vanuit het Ministerie van Onderwijs, Cultuur en Wetenschappen is de laatste jaren steeds meer oog voor het verbinden van de financieringsarrangementen voor de scholing van jongeren en ouderen. Daarnaast hebben de Ministeries van Sociale Zaken en Werkgelegenheid en Economische Zaken een toenemende betrokkenheid bij de employability van de werkenden en de niet-participerenden. Deze betrokkenheid vloeit voort uit het besef dat de employability van de beroepsbevolking een sleutelrol vervult in de kenniseconomie. 
Daarnaast is de toenemende betrokkenheid van de overheid het gevolg van de noodzaak een tweedeling op de arbeidsmarkt te voorkomen, in de zin van tekorten aan hoger opgeleiden in combinatie met een arbeidsoverschot aan lager opgeleiden of mensen die te maken hebben met kwalificatieveroudering.

Vergroten coherentie onderwijs-en arbeidsmarktbeleid

Door de veranderende betekenis van het post-initieel onderwijs in een kemnissamenleving raken de beleidsterreinen van de ministeries van Onderwijs, Cultuur en Wetenschappen, Sociale Zaken en Economische Zaken ook steeds meer met elkaar verweven. Hierdoor zijn de financiële middelen voor de scholing van werkenden en werkzoekenden in de huidige wetgeving sterk versnipperd geraakt: EZ-subsidieregeling, fiscale regelingen, Wet financiering loopbaanonderbreking, ESF, subsidieregelingen Arbeidsvoorziening en OC\&W-middelen (Ministerie SZW, 2000).

In het Nationaal Actieplan Werkgelegenheid zal het scholingsbeleid gericht op (langdurig) werklozen worden geïntegreerd met de scholing van werkenden. Hierbij gaat het zowel om de scholing van mensen zonder een "startkwalificatie" voor de arbeidsmarkt, als om de bij- of omscholing ter voorkoming van het verouderen van de kennis en vaardigheden. Deze op zich waardevolle stap in de integratie van het scholingsbeleid is mijns inziens echter nog onvoldoende. Voor zowel OC\&W, SZW als EZ neemt immers juist de herpositionering van het post-initieel onderwijs ten opzichte van het initieel onderwijs momenteel een prominente plaats in op de steeds meer op de kenniseconomie gerichte beleidsagenda. 
Dit alles pleit er mijns inziens voor de onderlinge positionering van deze drie Ministeries te heroverwegen. Dergelijke institutionele wijzigingen hebben de afgelopen jaren bijvoorbeeld ook in het Verenigd Koninkrijk plaatsgevonden. In 1995 is in het Verenigd Koninkrijk het Department for Education met het Employment Department samen gevoegd in het Department for Employment and Education (DfEE). Het Verenigd Koninkrijk is bepaald nog geen "gidsland" voor wat betreft de organisatie van het beroepsonderwijs. Van het DfEE gaat echter een krachtige impuls uit om hierin verandering te brengen.

Ik zou er daarom voor willen pleiten ook in Nederland een samenvoeging van de Ministeries van OC\&W en SZW te overwegen. De samenvoeging van beide departementen voorkomt het gevaar van een verkokering van het overheidsbeleid met betrekking tot het postinitieel onderwijs en het verrichten van dubbelwerk. Het zal ook het verbinden van de financieringsarrangementen voor de scholing van jongeren en ouderen in het initieel en post-initieel onderwijs kunnen bevorderen. Bovendien biedt het de basis voor het beëindigen van de institutionele scheiding tussen de onderwijsvoorzieningen en de sociale arrangementen voor werklozen en ouderen (zie ook De Vijlder, 2000). Het is in mijn ogen de brug die we moeten slaan om de coherentie in het onderwijs- en arbeidsmarktbeleid te vergroten en een geïntegreerd beleid te kunnen voeren ten aanzien van de initiële en post-initiële scholing en de employability van de beroepsbevolking, die een centrale rol vervullen in de kenniseconomie. 


\section{Besluit}

Terugblikkend op hetgeen ik hiervoor aan de orde heb gesteld, concludeer ik dat het toenemende belang van "een leven lang leren" in de kenniseconomie grote maatschappelijke consequenties heeft. Dit geldt zowel voor de urgentie van een adequate informatievoorziening, als voor onze eigen rol als werknemer, werkgever of beleidsmaker. Het betekent ook dat er op dit terrein nog veel te onderzoeken valt. Onderzoek dat maatschappelijk van groot belang is en ook tal van uitdagingen biedt voor het economisch onderzoek op het terrein van scholing en werk. Om op dit punt verder te komen zullen economen zich ook meer moeten verdiepen in het wetenschappelijk onderzoek in andere disciplines. Ik hoop hier vanuit mijn leerstoel een bijdrage aan te kunnen leveren. 
Van tweedekansonderwijs naar een leven lang leren 


\section{Dankwoord}

Aan het slot van dit betoog will ik graag een dankwoord uitspreken. Het College van Bestuur en de Stichting Wetenschapsbeoefening van deze universiteit wil ik bedanken voor mijn benoeming en het in mij gestelde vertrouwen. Ik stel het zeer op prijs een bijdrage te mogen leveren aan het onderzoek en onderwijs aan deze universiteit, die ik zoals ik reeds eerder aangaf, hoog acht. Dit laatste geldt niet alleen op het punt van de genoemde onderwijskundige kerncompetenties, maar zeer zeker ook voor het innovatieve onderzoek en onderwijs binnen de Faculteit der Economische Wetenschappen en Bedrijfskunde en de daarbinnen actieve onderzoeksinstituten. Ik hoop dat ik vanuit mijn leerstoel in het bijzonder ook een bijdrage kan leveren aan het versterken van de aanhechting van het onderzoek van het ROA bij het onderzoek en onderwijs van het departement Algemene Economie.

Ik will ook een aantal mensen persoonlijk bedanken. In de eerste plaats Hans Knol, mijn promotor aan de Vrije Universiteit.

Beste Hans, ik dank je voor je begeleiding aan het begin van mijn wetenschappelijke loopbaan. Je was een echte coach, die me steunde waar dat nodig was en vrij liet waar dat kon.

Mijn dank gaat ook uit naar Noé van Hulst, destijds mijn kamergenoot, die me op veel aspecten van het wetenschappelijk onderzoek een goed voorbeeld gaf en mijn werk altijd van kritisch commentaar voorzag. Deze rol, in al zijn aspecten, werd later overgenomen door Jules Theeuwes, mijn co-promotor. 


\section{Van tweedekansonderwijs naar een leven lang leren}

Veel dank ben ik ook verschuldigd aan Hans Heijke. Beste Hans, ik was de eerste onderzoeker die je bij het ROA aantrok. Je bood me van het begin af aan de mogelijkheid mede vorm te geven aan de ontwikkeling van het ROA. Je hebt een belangrijke rol gespeeld in mijn professionele doorgroei. Van het begin af aan delen we de ambitie onderzoek te doen dat zowel maatschappelijk als wetenschappelijk relevant is. Het ROA is daardoor uitgegroeid tot een fraai onderzoeksinstituut. Een groeipad dat niet zonder hobbels kon verlopen, maar waarop jij altijd een duidelijke visie bleef behouden.

Mijn dank gaat ook uit naar alle collega's van het ROA: secretariaat, onderzoekers, statistisch medewerkers en alle anderen die ons ondersteunen bij ons werk. Ik wil jullie allemaal bedanken voor jullie bijdragen aan het onderzoek. Bij vrijwel al onze publicaties is er sprake van teamwork. Hierin ligt denk ik een belangrijk deel van de kracht van ons werk. Ik heb er alle vertrouwen in dat er in de toekomst nog vele publicaties zullen volgen. Veel onderzoekers uit mijn afdeling heb ik reeds met naam kunnen noemen bij het bespreken van het onderzoek op het terrein van mijn leerstoel. Ik zal jullie namen hier niet herhalen. Het belang van mijn collega-afdelingshoofd Rolf van der Velden voor mijn eigen wetenschappelijke ontwikkeling bleef daarbij echter buiten beschouwing, vanwege de verschillende accenten in ons onderzoek. Dit wil ik hier rechtzetten. Beste Rolf, voor mij ben jij de belichaming van de belangrijke dingen die economen van andere sociale wetenschappers kunnen leren.

Lex Borghans en Jasper van Loo wil ik bedanken voor hun commentaar op een eerdere versie van deze rede en Jasper voor zijn hulp bij de PowerPoint presentatie. Verder gaat mijn dank uit naar Jozien Hendrikx voor het verzorgen van de gedrukte versie van mijn rede. 
Tot slot mijn familie. Veel dank ben ik verschuldigd aan mijn ouders, die mij altijd de vrijheid hebben gegeven mijn eigen keuzes in het leven te maken en mij altijd op alle mogelijke manieren ondersteunden in de wegen die ik insloeg. Mijn vader is helaas reeds zes jaar geleden overleden. Ook mijn moeder kan er vandaag jammer genoeg niet bij zijn. Haar dementie heeft haar bijna alles doen vergeten wat ze in haar leven heeft geleerd. Aan haar wil ik deze oratie opdragen.

Mijn dank gaat ook uit naar mijn schoonmoeder, die er gelukkig vandaag wel bij kan zijn. $\mathrm{Ze}$ is voor mij het levend voorbeeld van wat engagement in het leven kan betekenen.

Erg blij ben ik ook met mijn kinderen: Mila, Feiko, Benno en Jos. Het is fantastisch jullie te zien opgroeien. Als ik het plezier zie waarmee jullie voetballen, dansen, toneelspelen en ruzie maken met elkaar, besef ik steeds weer dat het in het leven niet alleen gaat om kennisverwerving.

Marise, met jou wil ik deze lezing afsluiten. Wat ben ik blij dat jij er bent. Je vormt de basis van mijn bestaan.

Ik heb gezegd. 
Van tweedekansonderwijs naar een leven lang leren 


\section{Literatuur}

Arrow, K.J. (1962), The Economic Implications of Learning by Doing, Review of Economic Studies, 24, pp. 155-173.

Arulampalam, W., A. Booth (1997), Who gets over the training huddle.. A Study of the Training Experiences of Young Men and Women in Britain, University of Warwick.

Barron, J.M., D.A. Black, M.A. Loewenstein (1989), Job Matching and On-theJob Training, Journal of Labour Economics, 7, pp. 1-19.

Barron, J.M., M.C. Berger, D.A. Black (1997), How Well Do We Measure Training, Journal of Labour Economics, 15, pp. 507-528.

Bartel, A.P. (1992), Training, Wage Growth and Job Performance. Evidence from a Company Database, NBER Working paper, no. 4027, Cambridge, Mass.

Becker, G.S. (1962), Investment in Human Capital: A Theoretical Analysis, Journal of Political Economy, 70, pp. 9-49.

Becker, G.S. (1964), Human Capital: A Theoretical and Empirical Analysis, With Special Reference to Education, National Bureau of Economic Research, New York.

Bloch, S. en T. Bates (1995), Employability. Your way to career success, Kogan Page, London.

Blundell, R., L. Dearden, C. Meghir, B. Sianesi, Human Capital Investment: The Returns from Education and Training to the Individual, the Firm and the Economy, Fiscal Studies, 20, pp. 1-23.

Borghans, L., J. Delmee, P. Marey, J.D. Vlasblom (1998), Toekomstverkenning arbeidsmarkt en scholing tot 2007, Ministerie wan Sociale Zaken en Werkgelegenheid, Den Haag.

Borghans, L., A. de Grip (1999), Smal en breed opleiden: productiviteil versus flexibiliteit, Gids voor de opleidingspraktijk, afl. 28, pp. 1-33.

Borghans, L., A. de Grip (2000), Skills and Low Pay: Upgrading or Overeducation?, in: M. Gregory, W. Salverda, S. Bazen (Eds.), Labour Market Inequalities, Oxford Uniwersity Press, Oxford, pp. 198-223. 
Borghans, L., A. de Grip, M. van Smoorenburg (1998), Measuring Skills Shortages, ROA-R-1998/4 ${ }^{\mathrm{E}}$, Maastricht.

Borghans, L., J. van Loo (2000), Sources of skills and the maintenance of human capital, Paper presented at the conference "Skill Measurement and Economic Analysis", University of Kent, March 27-29, 2000.

Borghans, L., J. van Loo, E. de Ruyter, M. de Steur, J. Sanders, J.D. Vlasblom (2000), Organisatieveranderingen en competentie-ontwikkeling. Verslag van een enquête bij het Kantoor, ROA-R-2000/3, Maastricht.

Braverman, H. (1974), Labor and monopoly capital: The degradation of work in the twentieth century, Monthly Review Press, New York.

Bresnahan, T.F., E. Brynjolfsson, L.M. Hitt (1999), Information Technology, Workplace Organization and the Demand for Skilled Labor: Firm-level Evidence, mimeo, Stanford, Cambridge (MA), Philadelphia.

Caroli, E. (1998), Technical Change, Work Organisation and Skills: Theoretical Background and Implications for Education and Training, in: Training for a Working Society, CEDEFOP, Office for Official Publications of the European Communities, Luxembourg, pp. 102-113.

Centraal Planbureau (2000), Centraal Economisch Plan 2000, Sdu, Den Haag. Cornet, M.F. (2000), Kaaskoppen verhandelen kemnis, Economisch Statistische Berichten, 85, pp. 99-101.

Crawford, V.P. (1990), Relation-Specific Investment, Quarterly Journal of Economics, 105, pp. 561-574.

Dekker, R., A. de Grip, H. Heijke (1996), Arbeidsmarktsegmentatie in Nederland, Tijdschrift voor Arbeidsvraagstukken, 12, pp. 338-351.

Diephuis, B., P. van Eijs, A. de Grip, G. Nekkers, J. Sanders (2000), De Limburgse arbeidsmarkt 1999-2004, ROA-R-2000/4, Maastricht.

Dool, P. van den, J. Moonen, A. Kraan (1999), Van didactische driehoek naar lerend veelvlak, NWO-PROO, Den Haag.

Dothan, U., J. Williams (1991), Education as an Option, Journal of Business, 54, pp. 117-139.

Dixit, A.K., R.S. Pindyck (1994, Investment under Unicertainty, Princeton University Press, Princeton.

Dronkers, J., E. van Eck (1998) Levenslang leren gezien vanuit de veranderende samenhang tussen school- en beroepsloopbanen, in: T.T.D. Peetsma, M.L.L. Volman (red.), Bevorderende en belemmerende factoren voor een 
leven lang leren. Exploratief onderzoek op micro-niveau, Sdu, Den Haag, pp. 11-22.

Dupuy, A., L. Borghans (2000), Firms' Responses in Recruitment to Labour Shortages and Surpluses, ROA, Maastricht (mimeo).

Dupuy, A., A. de Grip (2000), Occupational Reallocation in Response to Supply

Shocks, ROA, Maastricht (verschijnt binnenkort).

European Commission (1996), Teaching and learning. Towards the Learning Society, Brussels.

Eijs, P. van, H. Heijke (2000), Mismatch between Occupation and Education and the Costs of Job-related Training, in: H. Heijke, J. Muysken, Education and Training in a Knowledge-Based Econorny, Macmillan, London, pp. 159-189.

Fouarge, D., M. Kerkhofs, M. de Voogd, J.P. Vosse, Ch. De Wolf (1999), Trendrapport Aanbod wan arbeid 1999, OSA-publicatie A 169, Den Haag.

Fombrun, Ch.J., N.M. Tichy, M.A. Devanna (Eds.) (1984), Strategic Human Resource Management, John Wiley \& Sons, New York.

Friedlander, D., D.H. Greenberg, Ph.K. Robins (1997), Evaluating Government Training Programs for the Economically Disadvantaged, Journal of Economic Literature, 35, pp. 1809-1855

Gelderblom, A., J. de Koning (1992), Meer-jarig, minderwaardig. Een onderzoek naar de invloed van leeftijd op de produktiviteit en beloning, OSA V-39, SdU, Den Haag.

Gelderblom, A., J. de Koning (2000), Komt via ICT levenslang leren dichterbij?, in: A. de Grip, S. de Groot, K. Kuipers, M. Wolbers (red.), Alleen kennis werkt?, ROA/NAD-Maastricht, 2000.

Goux, D., E. Maurin (2000), Returns to firm-provided training: evidence from French worker-firm matched data, Labour Economics, 7, pp. 1-19.

Green, F. (1993), The Determinants of Training of Male and Female Employees in Britain, Oxford Bulletin of Economics and Statistics, 55, pp. 103-122.

Green, F., D. Ashton, B. Burchell, B. Davies, A. Felstead (2000), Are British Workers Becoming More Skilled?, in: L. Borghans, A. de Grip (Eds.), The Overeducated Worker? The Economics of Skill Utilization, Edward Elgar, Cheltenham, pp. 77-106. 
Greenhalgh, C. (1999), Adult Vocational Training and Government Policy in France and Britain, Oxford Review of Economic Policy, 15, pp. 97-113.

Greenhalgh, C., G. Mavrotas (1996), Job Training, New Technology and Labour Turnover, British Journal of Industrial Relations, 34, pp. 131150.

Grip, A. de (1985), Interne arbeidsmarkttheorieën: een overzicht, Maandschrift Economie, 49, pp. 333-345.

Grip, A. de (1987a), Onderwijs en arbeidsmarkt: Scholingsdiscrepanties (dissertatie), VU-Uitgeverij, Amsterdam.

Grip, A. de (1987b), Causes of Labour Supply and Demand Mismatches in the Dutch Building Trades, De Economist, 135, pp. 182-200.

Grip, A. de, R. Dekker (1993), Winnaars en verliezers op de arbeidsmarkt 19851990, Tijdschrift voor Arbeidsvraagstukken, 9, pp. 220-229.

Grip, A. de, L.F.M. Groot, J.A.M. Heijke, E.J.T.A. Willems (1990), De aansluiting tussen beroepen en functies en de relatie met scholings- en mobiliteitsprocessen, OSA-werkdocument W 80, Den Haag.

Grip, A. de, H. Heijke, E. Willems (1998), Training and Mobility, Netherlands' Journal of Social Sciences, 34, pp. 78-98.

Grip, A. de, A. Jacobs (1999), De betekenis van additionele scholing, Economisch-Statistische berichten, 84, pp. 416-418.

Grip, A. de, J. van Loo, J. Sanders (1999), Employability in action: an industry employability index, SKOPE Research Papers 5, University of Oxford/University of Warwick.

Grip, A. de, J. van Loo (2000), Winnaars en verliezers op de arbeidsmarkt 1990-1995, Tijdschrift voor Arbeidsvraagstukken, 16, pp. 6-17.

Grip, A. de, J. Sanders (2000), Naar een Employability Monitor, ROA, Maastricht (verschijnt binnenkort).

Grip, A. de, R.K.W. van der Velden (1999), Arbeidsmarktrelevantie studie onderwijswetenschappen, ROA-W-1996/6, Maastricht.

Groot, L.F.M., A. de Grip (1991), Technological Change and Skill Formation in the Banking Sector, Economics of Education Review, 10, pp. 57-71.

Groot, W., H. Maassen van den Brink (2000), Education, training and employability, Applied Economics, 32, pp. 573-581. 


\section{Van tweedekansonderwijs naar een leven lang leren}

Hall, D.T., J.E. Moss (1998), The new protean career contract: Helping organizations and employees adapt, Organizational Dynamics, 26, pp. 22-36.

Hartog, J. (1992), Capabilities, Allocation and Earnings, Kluwer Academic Publishers, Boston/Dordrecht/London.

Heckman, J.J. (1999), Policies to foster human capital, National Bureau of Economic Research, Working Paper 7288, Cambridge (Mass.).

Heckman, J.J., J. Smith (1995), Assessing the Case for Randomized Evaluation of Social Programs, Journal of Economic Perspectives, 9, pp. 85-110.

Hoekstra, H.A., E. van Sluijs (1999), Management van competenties. Het realiseren van HRM, Van Gorcum, Assen.

Howell, D., E.N. Wolff (1991), Trends in the growth and distribution of skills in the U.S. Workplace, 1960-1985, Industrial and labor Relations Review, 44, pp. 486-502.

Jones, E.B., J.E. Long (1979), Part-week work and human capital investment by married women, Journal of Human Resources, 14, pp. 563-578.

Jonker, N, A. de Grip (1999), Do employees with flexible contracts receive less training?, ROA-RM-1 999/1 ${ }^{\mathrm{E}}$, Maastricht.

Keep, E. (1999) Britain's VET Policy and the 'Third Way'. Following a High Skills Trajectory or Running Up a Dead End Street?, Paper presented at the ROA-Seminar, 15 april 1999, Maastricht.

Kessels, J. (2000), De academie in bedrijf. De omstreden dualisering van het wetenschappelijk onderwijs, Opleiding \& Ontwikkeling, 13, nr. 3, pp. 3339.

Killingsworth, M.R. (1982), "Learning by Doing" and "Investment in Training": A Synthesis of Two "Rival" Models of the Life Cycle, Review of Economic Studies, 49, pp. 263-271.

Koning, J. de (1998), Training for the unemployed in the Netherlands: what do we know after more than 50 evaluation studies?, Nederlands Economisch Instituut, working paper 1998/2, Rotterdam.

Lazear, E.P. (1995), Personnel Economics, MIT Press, Cambridge (Mass.)/ London.

Lueeuwen, S. van, J. Dronkers (1992), effects of continuing education: a study on adult education, social inequality, and labor market position, Journal of Educational Research, 17, pp. 609-624. 
Lemmink, J. (1999), Marketing en het hart voor de zaak, Universiteit Maastricht, Maastricht (oratie).

Lindbeck, A., D. Snower (2000), Multi-Task Learning and the Reorganisation of Work, from Tayloristic to Holistic Organization, Journal of Labor Economics, 18, pp. 353-376.

Loo, J. van, A. de Grip, M. de Steur (2000), Skills Obsolescence: Causes and Cures, International Journal of Manpower (verschijnt binnenkort).

Lynch, L.M. (1993), Entry-Level Jobs: First Rung on the Employment Ladder or Economic Dead End?, Journal of Labor Research, 14, pp. 249-263.

Lynch, L. M. (1998), A Needs Analysis of Training Data: What Do We Want, What Do We Have, Can We Ever Get It?, in: J. Haltiwanger, M.E. Manser, R. Topel, Labor Statistics Measurement Issues, University of Chicago Press, Chicago/London, pp. 405-426.

Lynch, L.M., S.E. Black (1998), Beyond the Incidence of Employer-Provided Training, Industrial and Labor Relations Review, 52, pp. 64-81.

Macdonald, G.M. (1982), A Market Equilibrium Theory of Job Assignment and Sequential Accumulation of Information, American Economic Review, 72, pp. 1038-1055.

Machin, S., J. van Reenen (1998), Technology and Changes in Skill Structure: Evidence From Seven OECD Countries, Quarterly Journal of Economics, 113, pp. 245-1279.

Marshall, A. (1890), Principles of Economics, Macmillan, New York.

Mincer, J, H. Ofek (1980), Interrupted work careers, National Bureau of Economic Research, Working Paper 479, Cambridge/USA.

Ministerie van Onderwijs, Cultuur en Wetenschappen (1998), Nationaal actieprogramma 'een leven lang leren'; Zoetermeer, 1998.

Ministerie van Onderwijs, Cultuur en Wetenschappen (1999), Ontwerp Hoger Onderwijs en Onderzoek Plan 2000, HOOP 2000, Zoetermeer.

Ministerie van Sociale Zaken en Werkgelegenheid (2000), In Goede Banen. Een aanpak van de knelpunten op de arbeidsmarkt, Den Haag.

National Skills Task Force (1999), Delivering Skills for All. Second Report, Department for Education and Employment/Prolog, Sudbury.

Nijhof, W. (1998), Curriculum Characteristics and Labour Market Perspectives, in H. Heijke en L. Borghans (Eds.), Towards a Transparant Labour Market for Educational Decisions, Ashgate, pp. 197-221. 
Nijhof, W.J., J.N. Streumer (Eds.) (1997), Key qualifications in work and education, Kluwer Academic Publishers, Dordrecht/Boston/London.

OECD (1995), Literacy, Economy and Society. Results of the first International Adult Literacy Survey, Paris.

OECD (1999), Employment Outlook June 1999, Paris.

Onstenk, J.H.A.M. (1997), Lerend leren werken. Naar een integratie van werken, leren en innoveren (proefschrift), Eburon, Delft.

Onstenk, J. (1998), Levenslang leren in bedrijven: een haalbare zaak?, in: T.T.D. Peetsma, M.L.L. Volman (red.), Bevorderende en belemmerende factoren woor een leven lang leren. Exploratief onderzoek op microniveau, Sdu, Den Haag, pp. 105-124.

Osterman, P. (1982), Employment Structures Within Firms, British Journal of Industrial Relations, 20, pp. 349-361.

Pillay, (1998), Cognitive skills required in contemporary workplaces, Studies in Continuing Education, 20, pp. 71-81.

Porter, M. (1997), Werken aan concurrentievoorsprong, in: R. Gibson (red.), Rethinking the Future. Visies op leiderschap, arganisaties, markten en de wereld, Thema, Zaltbommel, pp. 51-62.

ROA (1999), De arbeidsmarkt naar opleiding en beroep tot 2004, ROA-R1999/8, Maastricht.

ROA (2000), Werkgelegenheid en scholing 1999, ROA-R-2000/5, Maastricht.

Rosen, S. (1972), Learning and Experience in the Labour Market, Journal of Human Resources, 7, pp. 326-342.

Rosen, S. (1975), Measuring the Obsolescence of Knowledge, in: F.T. Juster (Ed.), Education, Income and Human Behavior, Carnegie Foundation, New York, pp. 199-232.

Schmid, G.J., J. O'Reilly, K. Schömann (1996), International Handbook of Labour Market Policy and Evaluation, Edward Elgar, Cheltenham/ Brookfield.

Schultz, T.W. (1975), The Value of the Ability to Deal with Disequilibria, Journal of Economic Literature, 13, pp. 827-846.

SER (1999), Advies HOOP 2000, Den Haag.

Shields, M. (1998), Changes in the determinants of employer-funded training for full-time employees in Britain. Oxford Bulletin of Economics and Statistics, 60, pp. 189-214. 


\section{Van tweedekansonderwijs naar een leven lang leren}

Simons, P.R.J. (1990), Transfervermogen, Katholieke Uniwersiteit Nijmegen, Nijmegen (oratie).

Smits; W., T. Stromback (2000), The Economics of the Apprenticeship System, Edward Elgar, Cheltenham.

Smoorenburg, M. van, A de Grip (1997), De scholingsinspanning van bedrijven: trainen of werwen, Economisch Statistische Berichten, $\mathbf{8 2}$, pp. 848-849.

Spencer, L.M., S.M. Spencer (1993), Competence at Work. Models for Superior Performance, John Wiley \& Sons, New York.

Stevens, M. (1994), A Theoretical Model of On-the-Job Training With Imperfect Competition, Oxford Economic Papers, 46, pp. 537-562.

Stevens, M. (1999), Human Capital Theory and UK Vocational Training Policy, Oxford Review of Economic Policy, 15, pp. 16-32.

Teulings, C.N. (1995), The wage distribution in a model of the assignment of skills to jobs, Journal of Political Economy, 103, pp. 280-315.

Teulings, C., J. Hartog (1998), Corporatism or Competition?, Cambridge University Press, Cambridge (UK).

Thijssen, J.G.L. (1996), Leren, leeftijd en loopbaamperspectief, Kluwer Bedrijfswetenschappen, Deventer.

Thijssen, J.G.L. (1997), Leren om te overleven. Over personeelsontwikkeling als permanente educatie in een veranderende arbeidsmarkt, Universiteit Utrecht (oratie).

Tinbergen, J. (1975), Income distribution: Analysis and Policies, North Holland, Amsterdam.

Waterman, R.H., J.A. Waterman, B.A. Collard (1994), Towards a careerresilient workforce, Harvard Business Review, 72, pp. 87-95.

Vijlder, F. de (2000), Leren in de vergrijzende economie, in: A. de Grip, S. de Groot, K. Kuipers, M. Wolbers (red.), Alleen kennis werkt?, ROA/NADMaastricht, 2000.

Welch, F. (1970), Education in Production, Journal of Political Economy, 78, pp. 35-59.

Wolff, E. (2000), Technology and the Demand for Skills, in: L. Borghans, A. de Grip (Eds.), The Overeducated Worker? The Economics of Skill Utilization, Edward Elgar, Cheltenham, pp. 27-56. 
Van tweedekansonderwijs naar een leven lang leren

Wood, A. (1994), North-South Trade, Employment and Inequality. Changing Fortunes in a Skill Driven World, Clarendon Press, Oxford.

Zolingen, S.J. van (1995), Gevraagd: Sleutelkwalificaties. Een studie natr sleutelkwalificaties voor het middelbaar beroepsondenwijs (proefschrift), Katholieke Universiteit Nijmegen, Nijmegen. 
Van tweedekansonderwijs naar een leven lang leren 